\title{
Opportunities for Public Participation \\ IN THE REGULATION OF \\ Hydraulic Fracturing OpERATIONS In Alberta
}

\author{
AlASTAIR LUCAS $^{*}$ AND HEATHER LILLES ${ }^{* *}$
}

\begin{abstract}
As the "anti-frack" movement gains momentum in society and the media, the oil and gas industry is faced with increasing demand for public participation and consultation in hydraulic fracturing operations. In Alberta, public participation has taken a number of forms, occurring during both the regulatory process and hydraulic fracturing operations themselves. This article analyzes the adequacy of these public participation opportunities by outlining the current opportunities for participation and the Alberta Court of Appeal's rulings regarding the adequacy of notification and consultation. Ultimately, the article concludes that despite a number of new regulatory initiatives, opportunities for public participation in hydraulic fracturing operations have not increased. However, the article remains optimistic that changes can and should occur, increasing opportunities for public participation and improving the timing and quality of such consultation.
\end{abstract}

\section{TABLE OF CONTENTS}

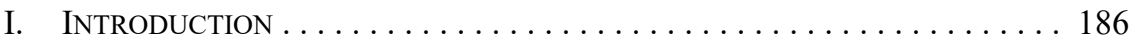

II. BACKGROUND AND SCOPE . . . . . . . . . . . . . . . . . . . . . . 189

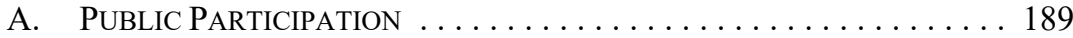

B. Hydraulic Fracturing Defined . . . . . . . . . . . . . . 192

III. Public PARTICIPATION OpPORTUNitiES

AT THE "Rule-Making" Stage . . . . . . . . . . . . . . . . . . . . . . . . . . . . . 194
A. AER Directive 083: HYDRAULIC FRACTURING,
SUBSURFACE INTEGRITY, AND THE REDA REGIME . . . . . . . . . 194
B. THE UNCONVENTIONAL RESOURCES
DisCUSSION PAPER AND PBR PILOT PROJECT . . . . . . . . . . . . . . 197

IV. Public PARTICIPATION OpPortunities

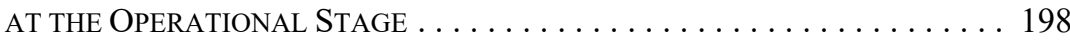

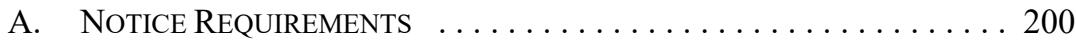

B. OpPORTUNITIES THROUGH THE AER'S

Alternative Dispute Resolution Process . . . . . . . . . . . 202

C. Public Consultation Opportunities and Directive 056 . . . . 202

D. The Regulator's Discretion, Directive 056,

AND THE Alberta COURT OF APPEAL . . . . . . . . . . 205

V. Public Consultation - Proposed New Requirements FOR HYDRAULIC FRACTURING OPERATIONS $\ldots \ldots \ldots \ldots \ldots \ldots \ldots . \ldots . \ldots 211$

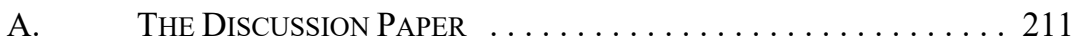

B. The Play-Based Regulation PRoject

(PBR PILOT PROJECT) . . . . . . . . . . . . . . . 213

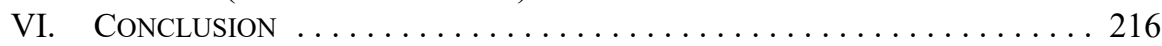

Professor of Law and Director, Sustainable Energy Development (SEDV) Program, University of Calgary.

** LLB, LLM Student, University of Calgary. 


\section{INTRODUCTION}

The increased use of hydraulic fracturing in the exploitation of oil and gas resources has led to a proliferation of "anti-frack" reporting in the global media. ${ }^{1}$ Interest groups have argued that hydraulic fracturing is a dangerous new technology that poses major risks to the environment and to the health and safety of an unsuspecting public. They have urged that the only reasonable response is to institute bans or moratoria on hydraulic fracturing. ${ }^{2}$

The province of Alberta and the Canadian oil and gas industry have responded to environmental health and safety issues and to the rising public concerns about hydraulic fracturing. Governments have adopted guidelines and rules aimed at identifying, assessing, and reducing the risks posed by this old, but newly enhanced and suddenly widely used technology. ${ }^{3}$

The increased use of hydraulic fracturing has coincided with an age of sophisticated communication and social media, along with growing non-governmental organization capability. This has led to more intense media scrutiny and a powerful demand for stakeholder and citizen engagement and consultation. ${ }^{4}$ Some media sources suggest that hydraulic fracturing is almost unregulated in Canada. ${ }^{5}$ Critics claim that Albertans are "in

1 George E King, "Hydraulic Fracturing 101: What Every Representative, Environmentalist, Regulator, Reporter, Investor, University Researcher, Neighbor and Engineer Should Know About Estimating Frac Risk and Improving Frac Performance in Unconventional Gas and Oil Wells" (Paper delivered at the SPE Hydraulic Fracturing Technology Conference, The Woodlands, Texas, 6-8 February 2012) at 1, online: $<$ https://fracfocus.org/sites/default/files/publications/hydraulic_fracturing_101.pdf $>$. Literature on hydraulic fracturing risks is voluminous, sometimes contradictory, and often inconclusive (ibid at $1-3)$.

2 Pierre Bertrand, “Quebec Installs Outright Moratorium on Hydraulic Fracturing," International Business Times (4 April 2012), online: <www.ibtimes.com/quebec-installs-outright-moratorium-hydraulic fracturing-433930>; Michael MacDonald, "Fracking on Hold for Two Years in Nova Scotia," Metro News (16 April 2012), online: <www.metronews.ca/news/halifax/2012/04/16/fracking-on-hold-for-twoyears-in-nova-scotia.html>; Michael MacDonald, "Nova Scotia Moves Ahead on Onshore Fracking Ban," The Globe and Mail (30 September 2014), online: <www.theglobeandmail.com/report-onbusiness/industry-news/energy-and-resources/nova-scotia-to-ban-high-volume-hydraulicfracturing/article20860189/>; Claudia Goodine, "Fracking Controversy: Rethinking the Low-Carbon Label for Natural Gas," Canadian Geographic (3 October 2011), online:<www.canadiangeographic.ca/ article/fracking-controversy>.

3 See e.g. Alberta Energy Regulator, "Hydraulic Fracturing," online: < www.aer.ca/rules-and-regulations/ by-topic/hydraulic-fracturing $>$ which lists nine separate regulatory directives that are applicable to hydraulic fracturing operations. It also includes links to: Alberta Energy Regulator, "Drilling and Hydraulic Fracturing in Alberta - Leading the Way" (19 March 2014), online: YouTube <https://www. youtube.com/watch?v=A74PLdXDIWM > ; Alberta Energy Regulator, "What is Hydraulic Fracturing?," online: <www.aer.ca/about-aer/spotlight-on/unconventional-regulatory-framework/what-is-hydraulicfracturing $>$. The Canadian oil and gas industry has also adopted a set of guidelines aimed at safeguarding human health and the environment and monitoring the effects of hydraulic fracturing operations: see Canadian Association of Petroleum Producers, Guiding Principles for Hydraulic Fracturing, 2012-0030 (Canadian Association of Petroleum Producers, December 2012), online: $<$ www. capp.ca/publications-and-statistics/publications/218125>.

$4 \quad$ Alastair R Lucas, Theresa Watson \& Eric Kimmel, "Regulating Multistage Hydraulic Fracturing: Challenges in a Mature Oil and Gas Jurisdiction" in Donald N Zillman et al, eds, The Law of Energy Underground (Oxford: Oxford University Press, 2014) 127 at 142.

$5 \quad$ See e.g. Dean Bennett, "Alberta Fracking An Unregulated Free-For-All, Licence Data Shows: NDP," The Canadian Press (4 February 2014), online: <www.huffingtonpost.ca/2014/02/04/alberta-frackingn_ 4724808.html>. 
danger of being shut out of discussions on how the province's natural resources are developed."

The purpose of this article is to examine the public consultation and participation side of these hydraulic fracturing issues. The focus is on protected rights and opportunities for the public to participate in the regulation of hydraulic fracturing operations in Alberta. In Part I current opportunities for public participation with respect to the regulation of hydraulic fracturing operations used in shale and tight oil and gas plays will be identified. This will involve consideration of (1) the opportunities for public participation available at the "rulemaking" or policy development stages of hydraulic fracturing regulation (and the legal basis for these opportunities); and (2) whether there has been an increase or decrease in overall opportunities for public participation as a result of two related energy resource regulatory initiatives introduced in Alberta. The first initiative, which focuses on unconventional oil and gas resources, was introduced by the Energy Resources Conservation Board (ERCB) in a Discussion Paper. ${ }^{7}$ This Discussion Paper was followed by the Alberta Energy Regulator's (AER, successor to the ERCB) Play-Based Regulation Pilot Project, which focuses specifically on hydraulic fracturing operations involved in shale gas plays. ${ }^{8}$

Part II explores the concept of public participation and why there is concern about public participation in hydraulic fracturing operations. A working definition of hydraulic fracturing is proposed for the purposes of the article. Potential concerns identified that are unique to hydraulic fracturing operations and have led to regulation of hydraulic fracturing operations separately from other oil and gas operations are examined.

Part III of the article explores the opportunities for public participation that were made available in the preparation and promulgation of AER Directive $083^{9}$ (which specifically pertains to hydraulic fracturing operations in Alberta), and in the more general Alberta energy regulatory reform which culminated in the development and implementation of the REDA Regime and the specific hydraulic fracturing initiatives currently underway. ${ }^{10}$ It is recognized that there is no individual or collective right to participate in rule-making of this nature. Nevertheless, there are strong pragmatic reasons for government agencies to develop opportunities for public participation in rule-making.

Bob Weber, "Oil Patch Critics Say Alberta Energy Regulator is Denying Them Right to Speak," The Globe and Mail (18 May 2014), online: <www.theglobeandmail.com/report-on-business/industry-news/ energy-and-resources/oilpatch-critics-say-alberta-energy-regulator-is-denying-them-right-to-speak/ article $18738361 />$.

7 Alberta, Energy Resources Conservation Board, "Regulating Unconventional Oil \& Gas in Alberta: A Discussion Paper" (Calgary: ERCB, December 2012) at 2, online: <www.aer.ca/documents/projects/ URF/URF_DiscussionPaper 20121217.pdf $>$ [Discussion Paper]. The original Discussion Paper [on file with author] has been amended. It has also been converted to an online presentation: Alberta Energy Regulator, "Alberta's Unconventional Oil \& Natural Gas" (Calgary: AER, 2013), online: <www.aer.ca/ documents/projects/URF/URF_Powerpoint.pdf $>$.

8 Alberta Energy Regulator, Play-Based Regulation Pilot Application Guide, Manual 009 (Calgary: AER, 14 July 2015), online: <https://aer.ca/documents/manuals/Manual009.pd > [PBR Pilot Project]. Alberta Energy Regulator, "Hydraulic Fracturing: Subsurface Integrity," Directive 083 (Calgary: AER, 21 May 2013), online: < https://www.aer.ca/documents/directives/Directive083.pdf> [Directive 083]. The "REDA Regime" refers to the Responsible Energy Development Act, SA 2012, c R-17.3 [REDA] (which established the Alberta Energy Regulator) and REDA's associated rules, regulations, and subordinate regulatory documents. 
Part IV examines the opportunities for public participation in oil and gas well operations in Alberta at the application or 'pre-hearing' stage. Currently, notification and consultation requirements for the drilling of all oil and gas wells in Alberta are outlined in the AER's Directive $056 .{ }^{11}$ The only mandatory requirements which pertain specifically to hydraulic fracturing operations are the hydraulic fracturing fluid disclosure requirements under Directive 059. ${ }^{12}$

Part IV then reviews and assesses the Alberta Court of Appeal's journey toward the view that the adequacy of notification and consultation prior to the issuance of an oil or gas resource-related approval in Alberta is primarily a matter of fact to be determined by the regulator, at its discretion.

Part V then compares these current, generally applicable opportunities for public participation, with the opportunities for public participation proposed by the regulator in the Discussion Paper on unconventional resources and the PBR Pilot Project. Arguably, by recognizing the unique nature of hydraulic fracturing operations, the Discussion Paper and the PBR Pilot Project purport to: (1) increase the timeliness of notification and consultation; (2) broaden the scope of notification and consultation to a more diverse group of stakeholders; and (3) consider a wider range of issues beginning with the issuance of Public Lands $\mathrm{Act}^{13}$ approvals to the cumulative effects of a particular shale gas project.

The article concludes that while there is no legal right to public participation at the rulemaking or policy development stage of hydraulic fracturing regulation, at each phase in the recent regulatory reforms, opportunities for participation were made available to the public and public input was actively sought by the regulators and the Alberta government.

With respect to the second question posed above, as we shall see, there has not been an increase or decrease in overall opportunities for public participation as a result of these regulatory initiatives. The Discussion Paper focuses generally on the development of unconventional oil and gas resources and outlines broad principles and goals. The PBR Pilot Project, which focuses specifically on hydraulic fracturing operations involving shale gas plays, is a policy based experiment. The same public participation opportunities which pertain to all oil and gas development in Alberta (largely contained in Directive 056) continue to apply to those operations which involve hydraulic fracturing.

Despite these conclusions, there are signs of a movement toward increasing public participation opportunities with respect to hydraulic fracturing in the future. If implemented, the Discussion Paper and PBR Pilot Project suggest that there will be expanded consultation requirements at the individual and community levels, which will include a wider definition of stakeholder, a more project-based approach, and a more comprehensive consultation on relevant issues.

11 Alberta Energy Regulator, “Energy Development Applications and Schedules,” Directive 056(Calgary: AER, 1 September 2011), online: <www.aer.ca/documents/directives/Directive056_April2014.pdf> [Directive 056].

$12 \quad$ Alberta Energy Regulator, "Well Drilling and Completion Data Filing Requirements,” Directive 059 (Calgary: AER, 19 December 2012), online: <www.aer.ca/documents/directives/Directive059.pdf> [Directive 059].

13 RSA 2000, c P-40. 
Before we can begin a more detailed analysis of these specific regulatory initiatives, we must first consider what public participation is, why it is a matter of concern in hydraulic fracturing operations, and propose a working definition of hydraulic fracturing for the purposes of this article.

\section{BACKGROUND AND SCOPE}

\section{A. Public Participation}

According to one of the foremost authorities on public participation in the natural resource development sector, public participation has been growing in democratic states as a means to improve decision-making. ${ }^{14}$ Further, the growth in public participation can be linked to the demands of the public to have their views heard. Referring to the work of Stuart Langton, ${ }^{15}$ Barton suggests that this increased demand is a result of the decline of mediating institutions such as the church and political parties, the ascendancy of the bureaucracy as a mechanism to justify government decisions, and the growth of mass media which give people more information about government activities. ${ }^{16}$ The growth of public participation in government decision-making in the natural resource sector also stems from the increasing impact of environmental decisions on citizens' lives, the growing awareness of the effects of environmental damage on human health and well-being, and the continuing development of human and political rights. ${ }^{17}$

But what is "public participation"? It has been described as "one instrument of deliberative democratic systems that seeks to capture the concerns and opinions of the people affected by government's decisions, or of the citizenry in general." ${ }^{\prime 18}$ For the purposes of this article, the definition of "public participation" adopted in a recent publication in the area of natural resources in Alberta will be used. There, public participation was defined broadly as "an all-encompassing label to describe any [and] all mechanisms that allow anyone other than government/governmental agencies and project proponents to communicate their views and influence decision making." 19

Who does this "public" encompass? First, it would include "landowners" and land occupants defined inclusively. Landowners are those whose land is the subject of a hydraulic fracturing operation and neighbouring landowners who consider themselves affected by

14 Barry Barton, "Underlying Concepts and Theoretical Issues in Public Participation in Resources Development" in Donald N Zillman, Alastair R Lucas \& George Pring, eds, Human Rights in Natural Resource Development: Public Participation in the Sustainable Development of Mining and Energy Resources (Oxford: Oxford University Press, 2002) 77 at 77-78.

15 Stuart Langton, "Citizen Participation in America: Current Reflections on the State of the Art" in Stuart Langton, ed, Citizen Participation in America: Essays on the State of the Art (Lexington, Mass: Lexington Books, 1978) 1.

Supra note 14 at 82 .

Ibid at $82-83$.

Rebeca Macias, Public Participation in Energy and Natural Resource Development: A Theory and Criteria for Evaluation, Occasional Paper No 34 (Calgary: Canadian Institute of Resources Law, 2010) at 1, online: <http://dspace.ucalgary.ca/bitstream/1880/48390/1/CriteriaOP34w.pdf>.

Nickie Vlavianos, "The Issues and Challenges with Public Participation in Energy and Natural Resources Development in Alberta" (2010) 108 Resources 1 at 2, online: <dspace.ucalgary.ca/bitstream/ 1880/47996/1/Resources108.pdf $>$ [Vlavianos, "Issues and Challenges"]. This definition was used for the purposes of a Round Table discussion at the University of Calgary on public participation in energy and natural resources developments in Alberta. 
hydraulic fracturing operations. Also contemplated are other industries, local governments and local communities potentially impacted by the fracturing operations, NGOs such as environmental groups and recreational groups, and other interested stakeholders and citizens. While Aboriginal peoples and Metis would also fall within this definition of the "public," the Crown's duty to consult with First Nations is a separate issue and beyond the scope of this article. $^{20}$

The justification for public participation in resource-related decision-making is multifaceted. In a comprehensive literature review on the issue, Macias concludes that public participation is a "valuable mechanism to produce good public policies related to energy and natural resources development." ${ }^{21}$ Specifically:

[F]irst of all, the fact that it is a human right for citizens to participate in the decisions that affect them.

Moreover, public participation lends legitimacy to a decision, promotes accountability of government policies and increases public trust towards the government. Public participation might also empower citizens through knowledge sharing. Finally, it may contribute to reducing costs and to optimizing the duration of the process, by anticipating and preventing bad decisions. ${ }^{22}$

However, Macias cautions that while public participation is a good instrument for environmental decision-making, it must also be conducted appropriately in order to be effective. $^{23}$

Despite the strong arguments in favour of public participation, in Alberta there is no general common law right to public participation prior to the drafting of legislation or

REDA, supra note 10, s 21 provides that the AER has no jurisdiction with respect to assessing the adequacy of Crown consultation associated with the rights of Aboriginal peoples. The Alberta Government, Aboriginal Consultation Office (ACO) is currently responsible for pre-consultation assessment, management, and execution of the Aboriginal consultation process. The ACO was founded in November 2013, but is not fully established. See Giorilyn Bruno \& Nigel Bankes, "The First Ministerial Direction to the Alberta Energy Regulator: The Aboriginal Consultation Direction" (23 April 2014), ABlawg (blog), online: <ablawg.ca/wp-content/uploads/2014/04/Blog GB NB Ministerial Order_April2014.pdf>; Giorilyn Bruno \& Nigel Bankes, “A Revised Aboriginal Consultation Direction Issue $\bar{d}$ to the Alberta Energy Regulator" (8 December 2014), ABlawg (blog), online: <ablawg.ca/wpcontent/uploads/2014/12/Blog_GB_NB_Min_Order_Dec2014.pdf $>$.

$21 \quad$ Macias, supra note 18 at 38

22 Ibid at 12-13. Despite the large volume of literature to the contrary, some continue to question both the need for public participation and the effectiveness thereof: see ibid at 2-3.

23 Ibid at 13. At 37-38, the criteria identified by Macias include the following considerations: the timeliness of the public participation; who has access to the decision-making process; is access based on clear and inclusive criteria; are access costs a factor; do the participants have sufficient knowledge of the decision-making process and timely notice opportunities to participate; to what degree is the regulator or the government accountable to consider the concerns and decisions elicited through public participation; and whether the process is transparent. Assessing the effectiveness of public participation in relation to hydraulic fracturing operations is beyond the scope of this article where the primary goal is more rudimentary - that is, identifying the opportunities for public participation in hydraulic fracturing related operations in Alberta. A large body of literature has arisen with respect to formulating theories of public participation and the criteria to assess the effectiveness of public participation (ibid at 13). See e.g. Jürgen Habermas, The Theory of Communicative Action: Reason and the Rationalization of Society, translated by Thomas McCarthy, vol 1 (Cambridge, UK: Polity Press, 1984) and the subset of literature which explores and critiques Habermas' work: Sherry R Arnstein, "A Ladder of Citizen Participation" (1969) 35:4 J American Institute Planners 216; Thomas Webler, "'Right' Discourse in Citizen Participation: An Evaluative Yardstick" in Ortwin Renn, Thomas Webler \& Peter Wiedemann, eds, Fairness and Competence in Citizen Participation: Evaluating Models for Environmental Discourse (Dordrecht: Kluwer Academic Publishers, 1995) 35 at 35; Patrick D Smith \& Maureen H McDonough, "Beyond Public Participation: Fairness in Natural Resource Decision Making" (2001) 14:3 Society \& Natural Resources 239; Gene Rowe \& Lynn J Frewer, "A Typology of Public Engagement Mechanisms" (2005) 30:2 Science, Technology, \& Human Values 251. 
subordinate legislation, such as regulations. There is equally no common law right prior to the creation of rules, guidelines, or policies made by government agencies and boards. Participation rights (or discretionary opportunities) must be statute-based.

At the federal level, the Statutory Instruments $A c t^{24}$ and the "Cabinet Directive on Regulatory Management" 25 govern the making of regulations. Section 15 of the Cabinet Directive specifically provides that "[d]epartments and agencies are responsible for identifying interested and affected parties, and for providing them with opportunities to take part in open, meaningful, and balanced consultations at all stages of the regulatory process." 26 This includes “pre-publication" in the Canada Gazette, Part I. Through the Canada Gazette, Part I, Canadians have a chance to submit their comments to the relevant government department or agency responsible for the proposed regulations, before the proposed regulations are enacted and published in Part II. $^{27}$

At the provincial level, Alberta has no statutory equivalent to the Statutory Instruments Act. The Alberta Regulations Act ${ }^{28}$ specifically addresses the notice and filing of regulations. There do not appear to be any public consultation requirements. However, according to the Government of Alberta's Service Alberta website, ${ }^{29}$ current regulatory reform activities include, inter alia, the engagement of external stakeholders. ${ }^{30}$ However, these objectives have not yet achieved the force of law.

Furthermore, the AER has chosen to regulate hydraulic fracturing operations primarily through the use of informal "rules" in the form of directives, guides, manuals, policies, and standards. Some would call this "rule-making." 31 It is beyond the scope of this article to affirmatively conclude whether AER directives have the legal weight of regulations; however, in these circumstances the answer is largely irrelevant at this time, for there is no statutory right to public participation in the development of either regulations or less formal "rules." 32

\section{RSC 1985, c S-22.}

Treasury Board of Canada Secretariat, "Cabinet Directive on Regulatory Management” (Treasury Board of Canada Secretariat, 2012), s 15, online: <www.tbs-sct.gc.ca/rtrap-parfa/cdrm-dcgr/cdrm-dcgrpreng.asp $>$ [Cabinet Directive].

Ibid, s 15.

Government of Canada, "The Canada Gazette,” online: <gazette.gc.ca/cg-gc/lm-sp-eng.html\#i5>. RSA 2000, c R-14. See also Regulations Act Regulation, Alta Reg 288/1999.

Government of Alberta, online: $<$ www.alberta.ca/regulations.cfm $>$.

See also Alberta, Red Tape Reduction Task Force, Focusing on What Matters: Report of the Red Tape Reduction Task Force (Edmonton: Red Tape Reduction Task Force, March 2012), online: <open. alberta.ca/dataset/cb47b9d5-e9a0-412b-9fd3-7b5291d6b798/resource/88279751-aad7-4ad1-ab38de9bcc1657ef/download/6027892-2012-03-RedTapeReductionReport.pdf $>$. Although this publication focuses on the regulatory impacts on small businesses, public consultation appears to be strongly supported (ibid at 4).

See Part III, below. REDA, supra note 10, ss 60-61 distinguishes between the power to make "rules" and the power to make "regulations." The power to make regulations is reserved to the Lieutenant Governor in Council. The AER is granted the authority to make rules.

Section 1(f) of the Regulations Act, supra note 28 defines "regulation" to mean "a regulation as defined in the Interpretation Act that is of a legislative nature." The Interpretation Act, RSA 2000, c I-8, s $1(1)(c)$ defines "regulation":

means a regulation, order, rule, form, tariff of costs or fees, proclamation, bylaw or resolution enacted

(i) in the execution of a power conferred by or under the authority of an Act, or

(ii) by or under the authority of the Lieutenant Governor in Council,

but does not include an order of a court made in the course of an action or an order made by a public officer or administrative tribunal in a dispute between 2 or more persons

Note also section 1(2) of the Regulations Act, ibid which provides: 


\section{B. HydraUlic Fracturing DeFined}

Around the world and in Alberta, there has been increasing exploitation of so-called "unconventional resources," which include shale gas and oil, coalbed methane (CBM), tight oil and gas, and oil sands resources. ${ }^{33}$ The primary focus of this article will be on the Government of Alberta's regulation of "shale" and "tight" oil and gas plays. ${ }^{34}$ Exploitation of shale gas alone was thought to be a "game changer" for the oil and gas industry and the Canadian economy. ${ }^{35}$

The marked increase in the exploitation of shale and tight oil and gas has occurred predominantly as a result of the development and application of advancements in several old technologies, namely "hydraulic fracturing" and "horizontal drilling." It has been argued that the lack of precise definition of hydraulic fracturing or "fracking" has led to misunderstandings and a wide discrepancy in concerns about the risks of these activities. ${ }^{36}$ "Fracking" operations have been defined narrowly with reference only to the "precise stimulation activity, limited to the fluid action in initiating and extending cracks in the rock." ${ }^{37}$ However, many stakeholders and citizens have defined fracturing broadly as equivalent to nearly every phase of the well development cycle, from drilling to production and arguably beyond. ${ }^{38}$

(2) The following are not regulations within the meaning of subsection (1)(f):

(d) a document adopted or incorporated by reference in a regulation.

Many of the AER Directives are referred to in the Oil Sands Conservation Act, RSA 2000, c O-7 and Oil and Gas Conservation Act, RSA 2000, c O-6 [OGCA]. This seems to be supported by the Regulations Act Regulation, supra note 28 which provides in section 17:

17(1) The following are exempt from the application of the Act:

(a) bylaws made under the Provincial Health Authorities of Alberta Act;

(b) all rules and orders made under the Oil and Gas Conservation Act, other than rules made under sections $10(1), 35,58$ and 59 of that Act;

(c) all rules and orders of the Alberta Energy Regulator under a provision of the Oil and Gas Conservation Act set out in clause (b).

See Discussion Paper, supra note 7 at 2. See also Council of Canadian Academies, Environmental Impacts of Shale Gas Extraction in Canada: The Expert Panel on Harnessing Science and Technology to Understand the Environmental Impacts of Shale Gas Extraction (Ottawa: CCA, 2014), online: <www. scienceadvice.ca/uploads/eng/assessments\%20and\%20publications $\% 20$ and $\% 20$ news\%20releases/ shale $\% 20 \mathrm{gas} / \mathrm{shalegas}$ fullreporten.pdf $>$ [Council Report]. Unconventional resources are comprised of essentially the same chemical compounds as "conventional" oil and gas, however they are produced in a different manner than "conventional" oil and gas and are found in different types of rock formations (Discussion Paper, ibid).

Shale gas plays typically involve low permeability 'shale' rock in which the natural gas is tightly locked. See Council Report, ibid at 18; Energy BC, "Hydraulic Fracturing: Fracking," online: <www.energybc. ca/profiles/naturalgas/fracking.html $>$ [EnergyBC, "Hydraulic Fracturing”]. It is often recognized that even within the "shale gas plays," not all hydraulic fracturing is the same: "differences in geology at the well site ensure the exact fracturing process varies" (EnergyBC, "Hydraulic Fracturing," ibid). Oil sands and coalbed methane extraction are generally regulated separately. Further, while it is recognized that hydraulic fracturing operations may be regulated federally to some extent, this article's primary focus is on Alberta's provincial regulatory regime.

Council Report, supra note 33 at xii.

King, supra note 1 at 4.

Ibid.

Ibid. For the purposes of this article, reference to "hydraulic fracturing" will refer to an oil and gas operating technique that "uses a specially blended liquid which is pumped into a well under extreme pressure causing cracks in rock formations underground ... [allowing] oil and natural gas to flow, increasing resource production": Frac Focus: Chemical Disclosure Registry, "Hydraulic Fracturing \& How it Works," online: < fracfocus.org/hydraulic-fracturing-process $>$. 


\section{WhAT IS UNIQUE ABOUT HyDRAULIC FraCTURING?}

There are distinct challenges associated with developing unconventional resources. Typically, unconventional developments "extend over broad areas and require a greater concentration of infrastructure to make production economically viable." ${ }^{39}$ Additional challenges relate to the protection and allocation of water resources, waste disposal, issues around high-pressure hydraulic fracturing, and the effects such activities can have on communities and the landscape. ${ }^{40}$

In April 2014, a report was released from the Council of Canadian Academies which was prepared for the Government of Canada in response to a request from the Minister of Environment. ${ }^{41}$ The Council was asked to assemble a panel of experts to address the following questions: "What is the state of knowledge of potential environmental impacts from the exploration, extraction and development of Canada's shale gas resources, and what is the state of knowledge of associated mitigation options?"42

The Council Report found that there was an overlap between many of the operational procedures used in conventional oil and gas extraction and those used in shale gas extraction. For example, the report recognized that the issue of "well integrity" applied to all types of wells. ${ }^{43}$ However, it also noted several aspects of shale gas development that could result in greater long-term impacts than conventional oil and gas operations. ${ }^{44}$

Particular to this article, the Council Report highlighted the importance of public engagement in the development of shale gas resources and the use of hydraulic fracturing operations. ${ }^{45}$ In the Executive Summary of the Council Report, the authors commented on the "public acceptability" of shale gas development:

The potential impacts of shale gas development, as well as strategies to manage these impacts, need to be considered in the context of local concerns and values. More specifically, the manner in which residents are engaged in decisions concerning shale gas development will be an important determinant of their acceptance or rejection of this development. To earn public trust, credible multidisciplinary research will need to be conducted to understand existing impacts and predict future impacts. ${ }^{46}$

Discussion Paper, supra note 7 at 2.

Ibid.

The Council of Canadian Academies is an independent, not-for-profit organization: Council Report, supra note 33 at iii.

Ibid at 2.

Ibid at xiii.

Ibid. For another analysis of some of the key issues involved in hydraulic fracturing, see Keith Luft, Thomas O'Leary \& Ian Laing, "Regulatory and Liability Issues in Horizontal Multi-Stage Fracturing," (2012) 50:2 Alta L Rev 403; Nigel Bankes, "Non-Conventional Oil and Gas Resources and the Legal Issues Associated with Hydraulic Fracturing in Canada," International Environmental and Resources Law Committee Newsletter (August 2013) at 4, online: <www.americanbar.org/content/dam/aba/ publications/nr_newsletters/iel/201308-2_ierl.authcheckdam.pdf $>$ [Bankes, "Non-Conventional"]. See also David Whee-er et al, Report of the Nov̄a Scotia Independent Review Panel on Hydraulic Fracturing (Sydney: Verschuren Centre for Sustainability in Energy and the Environment at Cape Breton University, 28 August 2014), online: <energy.novascotia.ca/sites/default/files/Report $\% 20$ of $\% 20$ the $\% 20$ Nova $\% 20$ Scotia $\% 20$ Independent $\% 20$ Panel $\% 20$ on $\% 20$ Hydraulic $\% 20$ Fracturing.pdf $>$.

Council Report, ibid at 208

Ibid at xvi. 
The Council Report proposed a framework for managing risks posed by shale gas development which includes five distinct elements. The fifth element directly addresses the engagement of local citizens and stakeholders. Conclusions included:

Public engagement is necessary not only to inform local residents of development, but to receive their input on what values need to be protected, to reflect their concerns, and to earn their trust. Environmental data should be transparent and available to all stakeholders. ${ }^{47}$

It is clear from this recommendation that effective consultations related to shale gas development will need to take place at different scales (e.g., local and regional), involve different stakeholders or population groups depending on the purpose of the consultation (e.g., residents to discuss minimizing nuisance issues; government planners to discuss water allocation or infrastructure needs), and take place at different stages of the operations cycle (e.g., seek input on exploration plans, report on activities). ${ }^{48}$

As we shall see in Parts IV and V of this article, Alberta regulators have attempted to address these issues in the context of hydraulic fracturing operations. But before a thorough analysis of these initiatives can be undertaken, it is instructive to determine what opportunities for public participation were available at the "rule-making stage" or policy development stage of hydraulic fracturing regulation (and the legal basis for these opportunities).

\section{Public Participation Opportunities AT THE "RULE-MAKING" StAGE}

\section{A. AER Directive 083: HYDRAUliC FraCturing, SUBSURFACE INTEGRITY, AND THE REDA REGIME}

The development in 2012 and early 2013 by the AER of Directive 083 was a classic example of rule-making by the Regulator. ${ }^{49}$ This directive replaced a predecessor directive — Directive 027, "Shallow Fracturing Operations." ${ }^{50}$ The question posed here is: what opportunities were there for public participation during the development of these "rules" and related policies and plans intended to govern hydraulic fracturing?

Rule-making does not involve making an individualized decision - one that affects an individual person or corporate entity directly. Rather, it is an expression of policy in formal terms so that lawmaking in a broader sense occurs. In the United States' federal Administrative Procedure Act, "rule" is defined as "the whole or part of an agency statement of general or particular applicability and future effect designed to implement, interpret, or prescribe law or policy." ${ }^{51}$ While the words "particular applicability" create ambiguity about the generalized character of rules, this characteristic alone does not determine whether a rule

Ibid at xix.

Ibid at 210.

Directive 083, supra note 9.

Alberta Energy Regulator, "Shallow Fracturing Operations: Restricted Operations," Directive 27 (Calgary: AER, 14 August 2009), online: <www.aer.ca/documents/directives/Directive027.pdf>.

Administrative Procedure Act, 5-2 USC § 551(4) (1946). 
has been created. ${ }^{52}$ Rather, the key definitional factor is the future effect of any agency action. ${ }^{53}$ Thus, rules can be broad, affecting large groups, or narrow, affecting considerably smaller groups in society. ${ }^{54}$

In Canadian administrative law, however, the scope of application may be more significant, depending on whether individual common law or statutory procedural fairness rights must be respected. ${ }^{55}$

Canadian courts have been reluctant to extend these common law participatory requirements to legislative functions that create general application norms of conduct. They have rejected procedural claims of groups affected by ministerial decisions that lay down policy applicable to the group. ${ }^{56}$ Public consultation processes will not be imposed on this kind of rule-making, even though this might be a "considerate thing" for the minister in question to do.$^{57}$ Nevertheless, there may be strong pragmatic reasons for agencies to adopt some type of public participation or consultation in rule-making. This apparently was the case for the Alberta Energy Regulator in its creation of new rules on hydraulic fracturing.

Development of the new hydraulic fracturing directive took place in the period when the entire Alberta energy regulatory framework was in flux. Enactment of the $R E D A^{58}$ and the transition from the Energy Resources Conservation Board (ERCB) to the AER was fraught with controversy. ${ }^{59}$ The roots are in the Alberta Government's Regulatory Enhancement Project (REP) ${ }^{60}$ which aimed at greater regulatory efficiency and accountability. A major issue was the proposed transfer of decision power concerning environment, water, and land use from Alberta Environment (and appeal functions from the Alberta Environmental Appeals Board) to the new Regulator. ${ }^{61}$ One element of this process was a discussion document: Enhancing Assurance: Developing an Integrated Energy Resource Regulator. ${ }^{62}$ Various informal consultation actions were based on this document. It is difficult to say precisely when public engagement on the REDA Regime began. However, the REDA Regime can trace its roots back to the REP, which started in 2010 with the establishment of the "Regulatory Enhancement Task Force." ${ }^{63}$ The Task Force was created to conduct "a comprehensive upstream oil and gas regulatory review and recommend system level reforms

52 Cornelius M Kerwin \& Scott R Furlong, Rulemaking: How Government Agencies Write Law and Make Policy, 4th ed (Washington, DC: CQ Press, 2011) at 6.

Ibid at 7 .

Ibid at 6 .

Homex Realty $v$ Wyoming (Village), [1980] 2 SCR 1011 at 1024-26.

See Canadian Association of Regulated Importers v Canada (AG), [1994] 2 FC 247 (CA) [Regulated Importers CA], rev'g [1993] 3 FC 199 (TD).

Regulated Importers CA, ibid at 259, Linden JA.

Supra note 10 .

See Nickie Vlavianos, "A Single Regulator for Oil and Gas Development in Alberta? A Critical Assessment of the Current Proposal" (2012) 113 Resources 1 at 1, online: <prism.ucalgary.ca/bitstream/ 1880/49151/1/Resources113.pdf $>$ [Vlavianos, "Single Regulator"].

60 Alberta Energy, "Regulatory Enhancement," online: <www.energy.alberta.ca/initiatives/regulatory enhancement.asp $>$.

61 See Nigel Bankes, "Bill 2 and Its Implications for the Jurisdiction of the Environmental Appeal Board" (9 November 2012), ABlawg (blog), online: < ablawg.ca/wp-content/uploads/2012/11/Blog NB Bill2 Jurisdiction_EAB_Nov2012.pdf $>$.

62 Government of Alberta, Enhancing Assurance: Developing an Integrated Energy Resource Regulator: A Discussion Document (Government of Alberta, 2011), online: <www.energy.alberta.ca/Org/pdfs/ REPEnhancingAssuranceIntegratedRegulator.pdf $>$ [Discussion Document].

63 Alberta Energy Regulator, "Regulatory Enhancement Task Force," online: <www.energy.alberta.ca/ Initiatives/3365.asp>. 
to ensure Alberta has a modern, efficient, outcomes-based and competitive regulatory system that continues to maintain Alberta's strong commitment to environmental management, public safety, and resource conservation." ${ }^{\circ 4}$

Stakeholders and First Nations participants had the opportunity to comment on the REP in a number of ways. Information sessions were held in September and October 2012. ${ }^{65} \mathrm{~A}$ series of in-person discussion sessions were held during June, July, and August 2011. ${ }^{66}$ A web-based survey of twelve questions was posted on the REP website, and Albertans were encouraged to comment on the direction proposed in the Discussion Document ${ }^{67}$ and answer the survey questions.

These consultation efforts were followed in the spring of 2013 when the Government of Alberta hosted 19 public sessions and a number of First Nation and Metis sessions, seeking feedback from Albertans on the REDA regulations. ${ }^{68}$ A report was issued summarizing the feedback received from these consultation sessions. ${ }^{69}$ During the public engagement sessions, Albertans, landowners, environmental groups, First Nations, industry, and municipalities provided feedback and answers to six questions. ${ }^{70}$

Additionally, an online survey was available for stakeholders to comment on these issues. According to the Consultations Report, it was the Policy Management Office's intention to consult with Albertans again in the Spring of 2014 to receive feedback on how the new system was working, and identify any issues that must be addressed. ${ }^{71}$

While this broad regulatory reform was in progress, hydraulic fracturing had come to public attention. The response was a Multi-Stakeholder Advisory Committee which recommended an assessment of the effects of hydraulic fracturing. ${ }^{72}$ From this Committee's recommendations and regulatory staff input came a draft directive in 2012. On 6 December 2012 the Regulator issued a Bulletin entitled "Invitation for Feedback: Hydraulic Fracturing Directive." ${ }^{, 73}$ The Bulletin provided the draft directive for review and feedback and noted that all feedback received would be posted on the ERCB's website. Further, the Bulletin provided that, at the discretion of the ERCB, comments received could be attributed to the individuals

\footnotetext{
Ibid.

Ibid.

Ibid.

Discussion Document, supra note 62 at 28.

Alberta Energy, "About Us: Regulatory Enhancement History," online: <www.energy.alberta.ca/ About Us/3991.asp >. Specifically, consultations on the regulations under the Responsible Energy Development Act were held in February and March 2013. More than 500 Albertans attended 19 public sessions, and approximately 350 people completed an online survey. Many other Aboriginal groups, key stakeholders, and individuals provided written input between February and June 2013: Alberta Energy, REDA Public Consultation Report (2013), online: <www.energy.alberta.ca/Org/pdfs/REDAPublic ConsultationSummary.pdf $>$.

69 Alberta Energy, Responsible Energy Development Act Regulations: Conversations with Albertans (Alberta Energy, 22 March 2013), online: <www.energy.alberta.ca/Org/pdfs/WWH_REDAconsult ations.pdf $>$ [Consultations Report].

Ibid at 1 . These questions pertained to the communication of notices and decisions of the Regulator, decision-making factors, hearings, Alternative Dispute Resolution, and the Landowner Registry.

Ibid at 7. There is no record on the REP website of such consultation occurring. See Alberta Energy, "Regulatory Enhancement," supra note 60.

Lucas, Watson \& Kimmel, supra note 4 at 143.

Alberta Energy Regulator, "Invitation for Feedback: Hydraulic Fracturing Directive," Bulletin 2012-24 (Calgary: AER, 6 December 2012), online: <www.aer.ca/documents/bulletins/Bulletin-2012-24.pdf>.
} 
providing them and the ERCB may use any personal contact information provided for follow-up communication. The deadline for response was 18 January $2013 .^{74}$

Even with this short and awkward time limit, in view of the holiday period, there was a considerable volume of public responses. It was necessary to extend the deadline to 4 February 2013. ${ }^{75}$ Subsequently, a summary of significant feedback was made available along with Regulator responses. ${ }^{76}$ A number of changes to the draft Directive were made. ${ }^{77}$

The result was that this voluntary, but formal, "notice and comment" rule-making process did engage a relatively small but committed group of participants. Modifications were made so that the final Directive 083 did reflect some of these public comments. But the voluntary nature of this rule-making exercise must be underlined. There is no legal right to public participation in rule-making of this kind.

\section{B. THE UNCONVENTIONAL RESOURCES Discussion PAPER ANd PBR Pilot Project}

As already noted, the AER is currently involved in a new regulatory initiative that involves the formulation of new AER rules for the development of unconventional hydrocarbon resources. The technique used involved the release of the initial Discussion Paper for public comment, followed by the PBR Pilot Project to test the proposed new regulatory approach in an area slated for new shale gas development.

In December 2012, the ERCB released a discussion paper entitled "Regulating Unconventional Oil and Gas in Alberta," which proposes a new separate regulatory scheme for unconventional resources development. ${ }^{78}$ This new scheme aligns with the "risk-based" regulatory reform movement and proposes co-operative, play-based development rather than compliance with prescribed standards and engineering and technological specifications. ${ }^{79}$

The PBR Pilot Project builds on the work completed under the Discussion Paper and represents the start of a change in the way that the AER regulates the energy sector: from activity-by-activity regulation to the regulation of multiple activities across large areas.

Alberta Energy Regulator, "Extension to Feedback Date for Comments on Draft Hydraulic Fracturing Directive," Bulletin 2013-02 (Calgary: ERCB, 8 January 2013), online: <www.aer.ca/documents/ bulletins/Bulletin-2013-02.pdf $>$.

76 Alberta, Energy Resources Conservation Board, "Directive 083: Hydraulic Fracturing: Subsurface Integrity Stakeholder Feedback and ERCB Responses" (Calgary: ERCB, May 2013), online: <www.aer. ca/documents/directives/Directive083-Feedback.pdf> [Directive 083 Response].

77 Ibid. These changes included: (1) additional requirements for wellbore integrity, design, and testing, including the option for single- and dual-barrier design; (2) the requirement to conduct comprehensive risk assessments related to interwellbore communication and nonsaline aquifers prior to the start of hydraulic fracturing operations; and (3) the requirement to conduct modeling prior to hydraulic fracturing operations to reduce the likelihood of interwellbore communication and prevent nonsaline aquifers from being adversely affected.

78 Discussion Paper, supra note 7 asserts that the current regulatory framework for oil and gas development "provides a solid foundation," however, Alberta must "build upon this base to address the unique issues, risks, opportunities, and challenges posed by unconventional resource development"(ibid at 2). Lucas, Watson \& Kimmel, supra note 4 at 133. 
The AER sought feedback after its release of the Discussion Paper on 17 December 2012, requesting input from Albertans on the new regulatory approach until 31 March $2013 .^{80} \mathrm{In}$ July 2014 the AER released the draft PBR Pilot Project, ${ }^{81}$ again requesting feedback and input from stakeholders (landowners, First Nations, municipalities, and other stakeholders in the region $)^{82}$ both within the pilot area boundaries and from stakeholders in general. ${ }^{83} \mathrm{On}$ 4 December 2014 the AER extended the dates for submitting an application pursuant to the PBR Pilot Project and also extended the end date of the project to 30 September $2015 .{ }^{84}$

However, as with the opportunities to participate in Directive 083, the opportunities for public participation in the PBR Pilot Project do not represent an open public review system designed to provide a forum for public interest participants and citizens. There is no legal requirement in Alberta for public consultation before the enactment of regulations. Steps are being taken towards notification of the public of impending legislation; however, at this time "public consultation" at the rule-making stage remains the subject of much discussion, yet little substantive action. ${ }^{85}$ However, as seen above, a number of public participation opportunities were available during the Alberta government's development of the REDA Regime, and more specifically, the AER has consistently offered the opportunity for public feedback and input in the creation of hydraulic fracturing directives and the new Discussion Paper and PBR Pilot Project. ${ }^{86}$

\section{Public Participation OpPortunities AT THE Operational Stage}

The AER provides public notice of public land applications for energy-related activities filed with the Regulator. All AER public land activity decisions are posted on its website. ${ }^{87}$ However, there are no formal opportunities for public participation when a person is granted mineral rights or surface rights on Crown land. ${ }^{88}$

ERCB, News Release, "ERCB Seeking Feedback on Regulatory Approach for Unconventional Development" (17 December 2012), online:<www.aer.ca/documents/news-releases/NR2012-13.pdf>. Alberta Energy Regulator, News Release, “Alberta Energy Regulator Pilots Play-Based Regulation Project” (2 July 2014), online: <www.aer.ca/documents/news-releases/AERNR2014-16.pdf>. PBR Pilot Project, supra note 8 at 8.

Alberta Energy Regulator, "Frequently Asked Questions: Play-Based Regulation (PBR) Pilot Project" (Calgary: AER, December 2014), online: <www.aer.ca/documents/about-us/PBR FAQ 2014 1204.pdf> [AER, "Frequently Asked Questions"]. PBR Pilot Project, supra note 8 at 17.

In 2015, regulatory reform initiatives were underway which purported to increase the engagement of external stakeholders. By October 2016, the relevant online documents had been taken down.

Further analysis will be necessary to assess the effectiveness of these public participation opportunities based on the factors identified in Part II, above.

Alberta Energy Regulator, "Public Lands Act," online: <www.aer.ca/applications-and-notices/applica tion-process/pla>. Pursuant to section 31 of REDA, supra note 10, the AER must ensure that public notice of all applications (including applications issued pursuant to the Public Lands Act, supra note 13) are provided in accordance with the Alberta Energy Regulator Rules of Practice, Alta Reg 99/2013 [REDA Rules].

Vlavianos, "Issues and Challenges," supra note 19 at 4. The industry applicant must acquire the mineral rights from either a freehold owner or the Crown, pursuant to Part 8 of the Mines and Minerals Act, RSA 2000, c M-17, Part 8 [MMA]. See also the Disposition and Fees Regulation, Alta Reg 54/2000. Under REDA, supra note 10, s 2(2)(e), jurisdiction for Part 8 of the MMA shifted to the Alberta Energy Regulator. An oil and gas operator is also required to obtain the relevant surface access rights from private landowners and occupants pursuant to the Surface Rights Act, RSA 2000, c S-24 [SRA]. Surface access to Crown land can be obtained from the AER pursuant to the Public Lands Act, supra note 13. Pursuant to REDA, the AER also took jurisdiction over issuing public lands dispositions as they relate to oil, gas, oil sands, and coal activity. Other approvals may be required for seismic exploration programs pursuant to Part 8 of the MMA, the Exploration Regulation, Alta Reg 284/2006 and associated Exploration Directives. 
Accordingly, the first opportunity for public participation in a proposed hydraulic fracturing operation occurs in conjunction with an operator's application to the AER for an approval to drill a well. This section of the article focuses on the opportunities for public participation at the "application stage" of a proposed hydraulic fracturing operation. At this stage there are three potential avenues for public participation. ${ }^{89}$ The first is participation through industry notification and consultation programs, which are regulated to a large degree by Directive $056 .^{90}$ The second avenue occurs through the environmental impact assessment process under the Environmental Protection and Enhancement Act. ${ }^{91}$ A third avenue arises under the provisions of REDA, ${ }^{92}$ the Responsible Energy Development Act General Regulation, ${ }^{93}$ and the REDA Rules. ${ }^{94}$ The latter currently involves the submission and acceptance of statements of concern and potential opportunities to participate in a regulatory hearing if one is held. This third avenue of public participation has been the subject of considerable jurisprudence and academic commentary, at least with respect to public participation in the pre-REDA Regime. ${ }^{95}$

It is recognized that significant opportunities for participation may be available pursuant to this third avenue; however, it is the first avenue that will be explored here - that is, the opportunities for public participation at the industry notification and consultation stage. Focus here is on well licence and related facilities applications. This is also the stage to which the regulator's new regulatory initiatives - the Discussion Paper and the PBR Pilot Project - are orientated.

The consultation and notification requirements at this stage are found largely within Directive 056. Industry applicants are required to engage in prescribed notification and consultation activities with specified segments of the "public." These notification and consultation requirements can result in differing opportunities for public participation. Whether notification and consultation is adequate in a particular case is largely a question of fact to be decided by the regulator. This section will attempt to identify the existing requirements for notification and consultation, and address how these requirements have allowed or restricted opportunities for public participation. ${ }^{96}$

This will be followed by a review of the Discussion Paper (and corresponding proposed regulation of unconventional resources) and the new PBR Pilot Project, both of which

Vlavianos, "Issues and Challenges," ibid at 5.

Supra note 11.

RSA 2000, c E-12 [EPEA]. At this stage, there is the possibility of public input (if not public determination) if an environmental impact assessment is required pursuant to $E P E A$ and the Environmental Assessment Regulation, Alta Reg 112/1993. However, the majority of energy project applications are exempted from the environmental impact assessment process. See the Environmental Assessment (Mandatory and Exempted Activities) Regulation, Alta Reg 111/1993, Schedule 2(e) and the Activities Designation Regulation, Alta Reg 276/2003.

Supra note 10.

Alta Reg 90/2013 [REDA General Regulation].

Supra note 87.

See Vlavianos, "Issues and Challenges," supra note 19 at 6-9. See also note 100, below.

The three primary statutes with respect to energy resource development do not directly speak to public participation: REDA, supra note 10, the OGCA, supra note 32, and the Pipeline Act, RSA 2000, c P-15 do not reference public consultation or participation. Instead, public consultation is largely confined to the requirements found in Directive 056, supra note 11. Directive 056 is incorporated by reference in the Oil and Gas Conservation Rules, Alta Reg 151/1971, s 1.020(2)(5.19), 2.010(1)(b), 2.020(4)(a), 11.010(1), 15.050(a), 15.210(a) [OGC Rules]; the Pipeline Rules, Alta Reg 91/2005, s 1(1)(g), 3(1), $3(3)(\mathrm{c}), 5(1), 5(2), 21(1), 72,74,82(2), 84,85(1), 85(2)$; and the REDA Rules, supra note 87, s 5.2(2)(a). 
attempt to address issues unique to unconventional resources, including hydraulic fracturing operations.

\section{A. Notice REQUIREMENTS}

Pursuant to section 31 of $R E D A,{ }^{97}$ the AER must ensure that public notice of all applications is provided in accordance with the REDA Rules. ${ }^{98}$ Section 5.1 of the REDA Rules prescribes the required content of public notices. ${ }^{99}$ Section 5.1 also provides the methods by which public notice of an application may be given. This includes posting notice of the application on the Regulator's website. ${ }^{100}$

Notice must also be provided pursuant to Directive 056 which requires project proponents to notify or consult with affected stakeholders depending on the circumstances. ${ }^{101}$ Notice requirements for well licence applications are based on surface proximity to the proposed well and the proposed well's sulphur content. Section 2.3.2 of Directive 056 specifies the circumstances in which "notification" is required. ${ }^{102}$ Section 2.3.1 addresses the circumstances in which personal consultation and confirmation of non-objection are required. $^{103}$ "Notification" differs from personal consultation in that the initial communication may take place through written correspondence rather than face to face or in telephone conversations. ${ }^{104}$

Section 2.2.2 of Directive 056 requires that "project-specific information packages" must be provided by the industry applicant to certain parties. ${ }^{105}$ These information packages must contain certain information about the proposed project including: the construction schedule; a description of the proposed energy development; the type of substance(s) that will be processed, transported, or drilled for; and a description of proposed on-site equipment. It is uncertain whether this information would alert a notified party that hydraulic fracturing will be conducted in a proposed operation. ${ }^{106}$

For hydraulic fracturing operations, Directive 083 provides that licensees must notify the ERCB a minimum of five days prior to the pressure test of surface equipment for hydraulic

97 REDA, supra note $10, \mathrm{~s} 31$.

98 Supra note 87.

$99 \quad$ Ibid, s 5.1 .

100 In the pre-REDA Regulatory Regime, the Department of Alberta Environment and Sustainable Resource Development (ESRD) received resource-related applications pursuant to EPEA, supra note 91 and the Water Act, RSA 2000, c W-3. Public notice was required pursuant to section 72 of the EPEA. Public notice was also required pursuant to section 37(1)(d) of the Water Act. An additional notice would then be issued to the ERCB that the ESRD was undertaking a review of the applications and associated environmental impact assessment, if required. The Energy Resources Conservation Board Rules of Practice, Alta Reg 98/2011, s 22(1) also provided that if the ERCB was considering deciding an application without a hearing, the Board could issue a notice of application. See Shaun Fluker, "Amended Rules of Practice for the Alberta Energy Regulator: More Bad News for Landowners and Environmental Groups" (11 December 2013), ABlawg (blog), online: <www.ablawg.ca/wp-content/up loads/2013/12/Blog_SF_AER_Rules_December-2013.pdf $>$ for a critique of the REDA notice provisions. 101 Supra note 11.

102 Ibid, s 2.3.2.

103 Ibid, s 2.3 .1 .

$104 \quad$ Ibid, s 2.3 .2 .

$105 \quad$ Ibid, s 2.2 .2 .

106

Ibid ("[t]he applicant must allow participants a minimum of 14 calendar days to receive, consider, and respond to notification of the proposed development" at s 2.2.1(5)). However, the industry applicant may file an application prior to the 14-calendar day period if certain conditions have been met. 
fracturing operations, as per the Hydraulic Fracturing Notification Submission Procedure. ${ }^{107}$ Directive 083 also requires hydraulic fracturing licensees to notify other licensees of "at-risk offset wells" and to engage and work cooperatively in the development of mutually acceptable well control plans. Upon becoming aware of any communication event with an offset well, licensees must immediately notify the affected offset well operator. ${ }^{108}$

There are currently no requirements in either Directive 056 or Directive 083 that specifically require notification of members of the public that a well's drilling program may include hydraulic fracturing operations. ${ }^{109}$ However, this information is available to the public upon request. The OGC Rules provide that the AER is to make available to the public certain information from records, reports, or information submitted to it or acquired by it in respect of oil and gas operations. ${ }^{110}$

The one area where we have seen an increase in public notification requirements which specifically pertain to hydraulic fracturing involves a response to public concerns about the adequacy of notification of the composition of fracturing fluids. This was addressed through the development of "Fracfocus.ca."" The FracFocus.ca website was originally built by the British Columbia Oil and Gas Commission and was based on the companion American site - FracFocus.org. ${ }^{112}$ The FracFocus.ca site provides that it is

a collaboration between provinces, territories, regulators and industry to provide Canadians with objective information on hydraulic fracturing, what legislation and regulations are in place to protect the environment including groundwater, and transparency on the ingredients that make up hydraulic fracturing fluids.... It is deliberately designed to provide the facts on issues that may be relevant to the public and is devoid of any "spin" or political commentary. ${ }^{113}$

Further, in Alberta, amendments were made to "Directive 059: Well Drilling and Completion Data Filing Requirements" to require public disclosure of hydraulic fracturing fluids on a well-specific basis. ${ }^{114}$ For wells fractured in Alberta after 31 December 2012, licensees are required to report fluid data, including service provider, fracture scenario,

Directive 083, supra note 9, s 8(29): "Notification is for one well licence or for a pad (multi-well) with continuous hydraulic fracturing operations." See Bankes, "Non-Conventional," supra note 44 (for a consideration of the other provisions of Directive 083 ).

Directive 083, ibid, s 3.3.4(14). If an "at-risk well" is an orphan well, the licensee includes the Orphan Well Association.

109 This article does not go so far as to suggest that such a requirement is warranted. According to an Alberta Energy News Release, "[a]pproximately 171,000 wells in Alberta have been stimulated using hydraulic fracturing since the technology was first introduced in the 1950s." Further, "[s]ince 2008, approximately 5,000 horizontal wells have been drilled in Alberta using multi-stage hydraulic fracturing to enhance oil and gas recovery." These statistics have only increased since 2012. See Government of Alberta, News Release, "ERCB Seeking Feedback on Regulatory Approach for Unconventional Development" (17 December 2012), online: <www.alberta.ca/release.cfm?xID=33443A9C3D0E6D822-AEC3-B349E12756888184>. Given the extensive use of hydraulic fracturing, it is questionable whether the benefits of notifying the general public prior to each hydraulic fracturing operation would outweigh the bureaucratic costs of such an undertaking. Supra note 96, ss 12.150(1)-12.150(12) (subject to certain restrictions regarding confidential wells and pools).

FracFocus Chemical Disclosure Registry, online: <www.fracfocus.ca $>$.

Ibid.

FracFocus Chemical Disclosure Registry, "Welcome," online: <www.fracfocus.ca/welcome>.

Alberta, Energy Resources Conservation Board, "Amendments to Directive 059: Well Drilling and Completion Data Filing Requirements in Support of Disclosure of Hydraulic Fracturing Fluid Information,"Bulletin 2012-25 (Calgary: ERCB, 19 December 2012), online: <www.aer.ca/documents/ bulletins/Bulletin-2012-25.pdf>; Directive 059, supra note 12. 
carrier fluid type, proppant type, and fracturing fluid chemical additive and ingredient. Water source data and water usage volumes are now also required to be reported. ${ }^{115}$ These changes followed a review of unconventional oil and gas rules that started in 2010 and a commitment to align some regulations with Saskatchewan and British Columbia." 116

\section{B. OPPORTUNITIES THROUGH THE AER'S Alternative Dispute Resolution Process}

One tool available to the AER to provide stakeholders with the opportunity to participate in a specific hydraulic fracturing application is the AER's "Alternative Dispute Resolution"117 (ADR) process, which replaces the "Appropriate Dispute Resolution" program under the (repealed) Energy Resources Conservation Act. ${ }^{118}$ The Regulator may use ADR when it considers it appropriate to do so for the purpose of resolving any issue or matter in dispute before the Regulator. ${ }^{19}$

Facilitation is the first stage of the ADR process and is optional. It involves an AER staff member, who is requested to assist by either the project proponents or stakeholders. ${ }^{120}$ However, if a party's concerns remain unresolved, a neutral third party mediator may be brought in to assist. This stage of the ADR process is also optional. ${ }^{121}$

The Regulator has the authority to require that both parties participate in an ADR process where appropriate. ${ }^{122}$ The terms of any agreement signed as a result of the use of alternative dispute resolution may be incorporated in and form part of a decision of the Regulator. ${ }^{123}$

\section{Public Consultation Opportunities And Directive 056}

As we have seen, the only public notification requirements which pertain specifically to hydraulic fracturing operations are those contained in Directive 059 respecting fracturing fluid disclosure. However, there do not appear to be any public consultation requirements

Ibid. Some exceptions apply.

Alberta, Energy Resources Conservation Board, News Release, "ERCB Improves Public Access to Hydraulic Fracturing Fluid Information FracFocus.ca Coming Soon to Alberta" (19 December 2012), online: <www.aer.ca/documents/news-releases/nr2012-14.pdf>. See also Directive 083 Response, supra note 76; Allan Ingelson \& Tina Hunter, "A Regulatory Comparison of Hydraulic Fracturing Fluid Disclosure Regimes in the United States, Canada, and Australia” (2014) 54:2 Nat Resources J 217 at 237-38.

Alberta Energy Regulator, Alternative Dispute Resolution Program and Guidelines for Energy Industry Disputes, Manual 004 (Calgary: AER, June 2013), online: <www.aer.ca/documents/manuals/Manual 004.pdf $>$ [Manual 004]. Manual 004 replaces and rescinds the Alberta Energy and Utilities Board, "Appropriate Dispute Resolution (ADR) Program and Guidelines for Energy Industry Disputes," Informational Letter IL 2001-1 (Calgary: Alberta Energy and Utilities Board, 8 January 2001), online: $<$ www.aer.ca/documents/ils/pdf/il2001-01.pdf $>$. See the Alberta Energy Regulator, "AER Issues Revised Publications to Reflect New Legislative Framework,"Bulletin 2013-01 (Calgary: AER, 17 June 2013), online: <www.aer.ca/documents/bulletins/AER-Bulletin-2013-01.pdf>.

Energy Resources Conservation Act, RSA 2000, c E-10, as repealed by REDA, supra note 10.

REDA Rules, supra note 87, ss 7.6(1)-(6) (grants the regulator broad discretionary powers with respect to what matters may be resolved by ADR and who may participate). But see ibid, s 7.6(3) (the restriction involving dispute resolution meetings convened with respect to regulatory appeals).

See Directive 056, supra note 11 (which adopts the language of those parties "directly and adversely" at A-55). But see Manual 004, supra note 117 (which is broader in scope, referring to "stakeholders" in general).

Directive 056, ibid at A-47.

REDA, supra note 10, s 46(1); REDA Rules, supra note 87, ss 7.6(1)-(6).

REDA, ibid, ss 46(1)-(2); REDA Rules, ibid, s 7.8 . 
which specifically address hydraulic fracturing operations. ${ }^{124}$ There is no mention of public consultation in Directive 083, which prescribes special regulatory requirements unique to hydraulic fracturing operations.

Directive 056 does not mention hydraulic fracturing operations. However, it does address horizontal wells and multi-pad operations - two practices which are often involved in hydraulic fracturing operations. As noted earlier, Directive 056 also applies to all oil and gas operations in Alberta, irrespective of whether hydraulic fracturing techniques are used. Accordingly, operators proposing hydraulic fracturing operations must comply with the public consultation requirements for general oil and gas operations in Directive 056. ${ }^{125}$

Section 2 of Directive 056 provides for "participant involvement" which involves two tiers of personal consultation and notification — required and expected. ${ }^{126}$ "Participant involvement" is broadly defined in Appendix 3 of Directive 056 as follows: "Participant involvement encompasses all aspects of public, industry, and regulator interactions and communications. It means that each organization, community, group, and individual with a stake in the discovery, development, and delivery of Alberta's resources may be a participant." 127 "Participant" is defined broadly in Appendix 3 as "An organization, community, group, or individual with a stake in the discovery, development, and delivery of Alberta's resources." 128

In section 2.1, Directive 056 provides:

Industry is required to develop an effective participant involvement program that includes parties whose rights may be directly and adversely affected ${ }^{129}$ by the nature and extent of a proposed application. The

While both the proposed Discussion Paper, supra note 7, and the PBR Pilot Project, supra note 8 specifically apply to hydraulic fracturing operations, as well as approval for other unconventional wells, the former is in the proposal stages only and the latter is voluntary. Both the Discussion Paper and the PBR Pilot Project are reviewed in detail below.

125 Directive 056, supra note 11 ("[t] $]$ he Energy Resources Conservation Board (ERCB) Directive 056: Energy Development Applications and Schedules presents the requirements and procedures for filing a licence application to construct or operate any petroleum industry energy development that includes facilities, pipelines, or wells," s 1.1). See also Alberta Energy Regulator, The Hearing Process for the Alberta Energy Regulator, Manual 003 (Calgary: AER, June 2013), online: <www.aer. ca/documents/manuals/Manual003.pdf $>$ [Manual 003]. Manual 003 provides that the purpose of the Manual is to explain the AER's hearing processes for energy projects to "assist members of the public who may be affected by a decision of the AER" (ibid, s 1.1).

Directive 056, ibid, contains both "requirements" and "recommendations." Recommendations or "regulatory expectations" are indicated by the words "recommends" and "expects" and represent recommended best practices or guidelines. "Regulatory requirements are those rules that industry has an obligation to meet." Enforcement action is only applicable to regulatory requirements (ibid, s 1.4). Ibid at Appendix 3.

Ibid.

The language of "directly and adversely affected" is not used frequently in Directive 056, ibid (with the exception of the appendixes). The term appears in the "overview" section of section 2.1 and two other less significant locations. The "directly and adversely affected" test has been the subject of considerable comment and analysis, specifically with respect to the pre-REDA Regime. See e.g. Nigel Bankes, "Shining a Light on the Management of Water Resources: The Role of an Environmental Appeal Board" (2006) 16:2 J Envtl L \& Prac 131; Cindy Chiasson, "Public Access to Environmental Appeals: A Review and Assessment of Alberta's Environmental Appeals Board" (2007) 17:2 J Envtl L \& Prac 141; Shaun Fluker, "The Right to Public Participation in Resources and Environmental Decision-Making in Alberta" (2015) 52:3 Alta L Rev 567 [Fluker, "The Right to Public Participation"]; Shaun Fluker, "Bill 2 Responsible Energy Development Act: Setting the Stage for the Next 50 Years of Effective and Efficient Energy Resource Regulation and Development in Alberta (8 November 2012), ABlawg (blog), online: < ablawg.ca/wp-content/uploads/2012/11/Blog_SF_Bill2_Nov2012.pdf $>$. More recently with respect to the REDA Regime, see Nigel Bankes, "Directly and Adversely Affected: The Actual Practice of the Alberta Energy Regulator" (3 June 2014), ABlawg (blog), online: <ablawg.ca/wp-content/ 
development and implementation of this program must occur prior to the filing of an application ... and include distributing the applicant's information package and the required ERCB publications, responding to questions and concerns, discussing options, alternatives, and mitigating measures, and seeking confirmation of nonobjection through cooperative efforts. ${ }^{130}$

An important consideration in any public participation program is the question of "who is engaged;" that is, who falls within the definition of the "public"? One concern of commentators has been that the "public" is too narrowly defined, and only a small segment of Alberta society is entitled to public notification and public participation opportunities in the context of oil and gas operations. ${ }^{131}$

Section 2.2.1 of Directive 056 asks the question "who to include" in participant involvement and provides that all parties within a specified radius and all parties with a direct interest in land must be included. ${ }^{132}$ Parties with a direct interest in the land may consist of landowners, residents, occupants, other affected industry players, local authorities, municipalities, and other parties who have a right to conduct an activity on the land, such as Crown disposition holders. The applicant must also include "those people that it is aware of who have concerns regardless of whether they are inside or outside the radius of personal consultation and notification indicated." ${ }^{133}$ Directive 056 provides in section 2.2 that "[i]t is industry's responsibility to assess the area beyond the specified distance to determine if the radius recommended by Directive 056 should be expanded. It may be necessary to increase the radius to include public interest groups or others who have expressed an interest in development in the area." 134

As we have seen, there is the potential in Directive 056 for the engagement of a broad spectrum of stakeholders through industry consultation and notification. In some respects, Directive 056 places the responsibility for developing and implementing an appropriate notification and consultation program on industry, although ultimately the AER has the discretion to decide whether an industry operator's consultation and notification program is sufficient.

A number of cases have also been brought before the Alberta Court of Appeal with respect to the adequacy of the AER's notification and consultation requirements. ${ }^{135}$ These cases will be reviewed next.

uploads/2014/06/Blog_NB_AER_June-2014.pdf>.

Directive 056 , ibid at s 2.1 [emphasis added].

Vlavianos, "Issues and Challenges," supra note 19 at 8-9; Fluker, "The Right to Public Participation," supra note 129.

Directive 056, supra note 11, s 2.2.1.

Ibid, s 2.2.1(4).

Ibid, s 2.2 .

Note the difference between the Court's review of the regulator's assessment of the adequacy of existing notification and consultation requirements versus questions of standing. At its most basic definition, legal standing equates to the right of a party to participate in a hearing (whether written or oral) or court proceeding. See Cindy Chiasson, "What's Standing and Why Should You Care?" (2011) 26:1 Environmental L Centre News Brief 1, online: <elc.ab.ca/Content Files/Files/NewsBriefs/Vol26No1 Web.pdf $>$ [Chiasson, "What's Standing"]. Questions of standing are beyond the scope of this article; however, it is recognized that we are imposing a somewhat artificial separation between pre-hearing consultation and notification and issues of standing. 


\section{The Regulator's Discretion, DireCtive 056, AND The Alberta Court Of APPEAL}

The Court of Appeal has held that the "consultation requirements mandated by the law in Directive $056 " 136$ are largely questions of fact for the Board to consider. In the case of PetroCanada, several interveners applied for leave to appeal a decision of the ERCB approving a project to drill 11 gas wells, construct a battery, and build a gathering system of pipelines and a trunkline. ${ }^{137}$ Several of the interveners specifically sought leave to appeal on the ground that the Board erred in law by ignoring the failure on the part of the industry applicant to consult adequately with stakeholders on alternative trunkline routing.

Two of the intervener groups submitted that the industry applicant had failed to provide more detailed information concerning alternate routes, which violated their right to be informed of facts or allegations contrary to their interests, and the right to cross-examine on those allegations. They further submitted that the industry applicant had failed to meet the requirement of a "'thorough and effective public consultation program that goes well beyond the normal consultation process because of the potential sensitivity of the eastern slopes area." "138

The Court in Petro-Canada noted that the Board had concluded that the industry applicant had conducted a thorough and accessible public consultation program that met the requirements of Directive 056 and IL 93-9. ${ }^{139}$ However, the Court noted that the Board also recognized that there was a lack of consultation prior to the hearing and that consultation about alternatives in advance of the hearing might have " made the hearing more efficient' and clarified the issues." 140

Further, the Court noted at para 13 that "[i]t is not uncommon that defects in consultation are addressed at the hearing itself." 141 In the case before the Court, the industry applicant argued that there had been a complete exchange of views about alternative routes at the

Big Loop Cattle Co Ltd v Alberta (Energy Resources Conservation Board), 2010 ABCA 328, (sub nom Re Petro-Canada) 490 AR 246 at para 14 [Petro-Canada].

Ibid.

Petro-Canada, supra note 136 at para 12. See also Alberta Energy and Utilities Board, "Oil and Gas Developments Eastern Slopes (Southern Portion)," Informational Letter IL 93-9 (Calgary: Alberta Energy and Utilities Board, 13 December 1993) [IL 93-09], online: $<$ www.aer.ca/documents/ils/pdf/il9309.pdf $>$. The reference to the "eastern slopes area" is a reference to the ERCB's special regulatory requirements for the development along the southern portions of Alberta's Eastern Slopes. These special requirements include "a thorough and effective public consultation program consistent with the sensitivity of the area proposed for development" and an environmental assessment for each proposed development stage (ibid).

Petro-Canada, supra note 136 at para 13.

Ibid, citing Petro-Canada Applications for Eleven Well Licences, One Multiwell Gas Battery Licence, and Two Pipeline Licences Sullivan Field (8 June 2010), 2010-022 at 10, online: <www.aer.ca/ documents/decisions/2010/2010-022.pdf $>$.

Petro-Canada, ibid at para 13. 
hearing, where the parties had ample opportunity to state their concerns. ${ }^{142}$ The Court agreed, and leave to appeal was denied on that ground. ${ }^{143}$

Another example of the Court of Appeal being asked for leave to appeal a decision of the ERCB on the grounds that the public consultation program of the industry applicant was inadequate was Berger v. Alberta (Energy Resources Conservation Board) ${ }^{144}$ In this case, the Board had granted the industry applicant authorization to drill three sour gas wells. Community members brought an application for leave to appeal based on over ten grounds, a number of which involved the alleged failure of the Board to enforce specific provisions of Directive 056 . For example, it was argued that the industry applicant failed to consult with interested parties up to the time of the hearing, as required by Directive $056 .{ }^{145}$ The Court of Appeal noted that the Board was aware of the issue, but ruled that "at some point there must be closure in public consultation." ${ }^{146}$ Further the Court noted:

There are previous decisions granting leave to appeal issues arising from the interpretation of ERCB Directive 056, but that does not mean that every application engaging ERCB Directive 056 warrants leave to appeal. Each issue must be examined individually. For example, in Graff v. Alberta (Energy and Utilities Board), 2007 ABCA 20 (CanLII) it was argued that ERCB Directive 056 unlawfully fettered the Board's discretion. The alleged error in Graff was in applying ERCB Directive 056; here the alleged error is in the non-application of ERCB Directive 056. The issues are different in character, and the standard of review is possibly different. $^{147}$

The applicants also argued that the industry applicant had failed to submit a Participant Involvement Summary Form and that this form was a mandatory part of the application. ${ }^{148}$ The Court of Appeal noted that, pursuant to section 2.010(1)(b) of the OGC Rules, ${ }^{149}$ an application for a licence "shall ... include the documentation required by Directive 056 " and that this was authorized by the OGCA. ${ }^{150}$

The Court confirmed that section 10(1)(a) of the OGCA gave the Board authority to make regulations prescribing the information to be included in an application. However, the Court added that section 10(4) of the OGCA provided that the Board was not "precluded from considering or acting on an application" that did not contain the required information. ${ }^{151}$ The Court of Appeal in Highpine concluded:

Ibid. See also SemCAMS ULC v Alberta (Energy Resources Conservation Board), 2010 ABCA 397, 96 CPC (6th) 46 [SemCAMS cited to CPC] where the Applicants for leave to appeal argued that the Board had failed to consider the informational and consultational requirements of a "Proliferation Policy." Justice Paperny of the Court of Appeal concluded that " $\mathrm{t}]$ he determination as to the adequacy of the consultation is a factual question not reviewable on appeal" (SemCAMS, ibid at para 17). Petro-Canada, ibid at paras 49-50. The Court of Appeal did grant leave to appeal on the question of whether the Board erred in law by failing to characterize the Eden Valley Reserve as an urban centre. 2009 ABCA 158, (sub nom Re Highpine Oil \& Gas Ltd) 2009 ABCA 158 (CanLII) [Highpine]. Ibid at para 6; specifically, the Applicants argued that there was a breach of section 2.5(53) and (54) of Directive 056, supra note 11.

Highpine, ibid at para 6.

Ibid at para 7 .

Ibid at para 8; specifically, the Applicants argued that this was in breach of section 7.11.2.2 (91) of Directive 056. The Applicants also pointed to other alleged examples of non-compliance with other provisions of Directive 056, supra note 11.

Supra note 96, s 2.010(1)(b).

Highpine, supra note 144 at para 9, citing OGCA, supra note 32, s 10(4).

Highpine, ibid at para 9, citing OGCA, ibid. 
Even if the requirement for a Participant Involvement Summary Form is "mandatory", the mere absence of that Form does not preclude the Board from processing the application. The Regulations and Directive 056 are subordinate legislation, and cannot be interpreted as removing the discretion given to the Board under s. 10(4) of the Act. Given the wide powers held by the Board under s. 10(4), and given the standard of review that would apply, the argument respecting missing information does not have sufficient substance to warrant leave to appeal. ${ }^{152}$

The Court of Appeal ultimately dismissed the application for leave. ${ }^{153}$ The Court of Appeal's decision in Highpine was cited by the Court in Big Loop Co et al. v. Energy Resources Conservation Board (Alta.) et al. ${ }^{154}$ This case involved an appeal from an ERCB decision granting an application to construct two sour gas pipelines. The Court of Appeal held that the Board had erred in law in interpreting and applying certain definitions found in Directive 056. Further, the Court's analysis on the appropriate standard of review addressed the nature of Directive 056 and the significant discretion of the Board in the application of its own directives:

The Directives are "home rules" drafted, promulgated, revised, amended and repealed by the Board. The introduction to Directive 056 describes it as both a procedural manual on how to file a licence application and a regulatory document on the licence application process.... Directive 056 forms part of the Board's own statute, a statute which is closely connected to its function, and with which the Board has particular familiarity.... Indeed, in denying leave to appeal in [Highpine], this court afforded significant discretion to the Board in the application of its own directives (at para 9). ${ }^{155}$

In 2007, the Alberta Court of Appeal issued its opinion in Graff v. Alberta (Energy and Utilities Board). ${ }^{156}$ Although the Graff case is more properly characterized as a decision on standing, Justice Hunt granted the Applicant's leave to appeal the Board's decision with respect to one of the wells on the basis that the Board had erred in its interpretation and application of Directive 056. ${ }^{157}$

With respect to the second leave to appeal application and the 4-22 Well, the Court of Appeal in Graff held that the Board did not have medical evidence concerning the Appellants' claim, and the Appellants chose not to meet with the industry applicant or provide further evidence. ${ }^{158}$ With regard to the first leave to appeal application and the 1-25

\section{Highpine, ibid.}

Ibid at para 18. Also at issue before the Court was the appropriate interface between privacy legislation and the requirements of Directive 056. See Alberta, Information and Privacy Commissioner, "Report on an Investigation Regarding the Disclosure of Personal Information by the Alberta Energy and Utilities Board," an Investigation Report F2007-IR-002 (Edmonton: OIPCA, 7 March 2007), online: $<$ https://www.oipc.ab.ca/media/127800/F2007-002IR.pdf $>$ (which concludes that public disclosure of the substance of the objections to an application for a licence is legitimate). See also Highpine, ibid at paras $15-16$.

2012 ABCA 64, (sub nom Re Petro-Canada) 522 AR 325 [Petro-Canada 2012 cited to AR].

Ibid at para 10.

Graff v Alberta (Energy \& Utilities Board), 2008 ABCA 119, 2008 ABCA 119 (CanLII) [Graff cited to CanLII]. Graff was the compilation of two separate applications which had both been granted leave by the Court of Appeal on questions of standing with respect to two well licenses (the 1-25 and 4-22 wells) that the Board had granted.

See Graff v Alberta (Energy \& Utilities Board), 2007 ABCA 246, 30 CELR (3d) 161 with respect to the 1-25 Well. See also Graff v Alberta (Energy \& Utilities Board), 2007 ABCA 20, 2007 ABCA 20 (CanLII) (the Applicants received leave to appeal the decision on the 4-22 Well on the basis that the Board had, inter alia, disregarded, misapplied, or misinterpreted Directive 056 at para 9).

Graff, supra note 156 at para 21 . 
Well, the Board also had no medical evidence before it to support the Appellants' claims that they may be directly and adversely affected by the well.

In Graff, the Court concluded:

$[\mathrm{T}]$ here is nothing in the legislation or the Board's procedures mandating the Board to consult with the appellants in these circumstances.

In these appeals, the Board was asked to re-consider earlier decisions. It was not unreasonable for the Board to require the parties requesting the review, on the basis that they suffered from an unusual sensitivity to natural gas [wells], to provide more than a mere assertion of that sensitivity. The appellants failed to do so. On that basis, we find no error or denial of natural justice when the Board declined to review their earlier decisions. $^{159}$

Further, the Court held that the Appellants' submissions on the issue were "largely fact laden and not questions of law." 160 The facts showed that the Appellants did not place relevant information before the Board. Had they done so, and had the Board then declined to hear them, the question of the Board's interpretation of their governing legislation and their procedural fairness obligations may have raised an issue of misinterpretation or the fettering of the Board's discretion. ${ }^{161}$

Another series of cases, again primarily addressing the issue of standing before the regulator, also indirectly addressed the adequacy of consultation pursuant to Board Directives. ${ }^{162}$ The first of these cases, and the one most relevant to the issues considered here, was Kelly \#1. ${ }^{163}$ In this case, the Court held that the operation of a number of ERCB directives, including Directive 056, resulted in the creation of legal rights which were sufficient to meet the first requirement for standing. ${ }^{164}$ More significant for the adequacy of consultation, the Court was asked to determine whether Directive 056 required that the applicant landowners should have been included in the industry consultation process. The Court held:

Ibid at paras 25-26.

Ibid at para 27.

Commentators were disappointed in Graff, ibid, arguing that the decision was a "lost opportunity" for the Court of Appeal to clarify "certain key public participation issues in oil and gas development": Nickie Vlavianos, "A Lost Opportunity for Clarifying Public Participation Issues in Oil and Gas Decision Making” (10 May 2008), ABlawg (blog), online: <ablawg.ca/wp-content/uploads/2009/09/ blog nv graff abca may2008.pdf $>$. See Kelly et al $v$ Energy Resources Conservation Board (Alta) et al, 2009 ABCA 349, 464 AR 315
[Kelly\#1]; Kelly v Alberta (Energy Resources Conservation Board), 2012 ABCA 19, 519 AR 284 [Kelly \#4c]; Kelly v Alberta (Energy Resources Conservation Board), 2011 ABCA 325, 515 AR 201 [Kelly $\# 3 \mathrm{~b}]$.

In Kelly \#4c, ibid, the landowner applicants from Kelly \#1 appealed a decision of the ERCB refusing intervener costs. The issue of access to costs is a critical component when considering the public's ability to effectively take advantage of an opportunity to participate in an energy resource review. Although the issues surrounding the availability of costs to participate in regulatory hearings are beyond the scope of this article, it is recognized that the issue of costs is significant to the question of the effectiveness of the opportunities for public participation. Further, the Court of Appeal's decision in Kelly \#4c is independently significant for the Court of Appeal's comments with respect to public participation in resource review applications. However, these comments pertain largely to public participation in hearings, which is, again, beyond the scope of this article's review: see Kelly \#4c, ibid at para 34.

Kelly\#1, supra note 162 at paras 26-33. 
Specifically, Directive 056, paragraph 2.2.1 entitled "Who to Include" directed that Grizzly develop a "participant involvement program" including three groups, those who resided within the EPZ, "all parties whose rights may be directly and adversely affected", and people who had special needs or concerns resulting from the drilling applications. For the reasons given below the Appellants are members of the second group and were thus entitled to be included in the participant involvement program. ${ }^{165}$

Consequently, it could be argued that the Alberta Court of Appeal was willing to interfere with the regulator's interpretation of its own directive, at least with respect to who was owed consultation pursuant to Directive 056. However, after the Kelly\#1 decision was issued, the ERCB released Bulletin 2009-41, ${ }^{166}$ which explained that the Court of Appeal's interpretation in the Kelly \#1 decision varied significantly from the ERCB's intentions. Accordingly, the ERCB revised the directives in question to provide greater clarity on certain prescribed planning and emergency response zones and the resident stakeholders who might be affected.

The Alberta Court of Appeal has addressed allegations with respect to the fettering of discretion in Directive 056, the regulator's misapplication of Directive 056, regulator noncompliance with Directive 056, and, to some extent, the regulator's jurisdiction to enact Directive 056. The issue of the precise legal status of AER Directives and Directive 056 in particular is an issue that has yet to be fully addressed. According to one commentator, "ERCB Directives are most definitely evidence of something — at the very least they impose policy obligations on the energy industry and in some cases these obligations have the force of law as regulations enacted pursuant to applicable legislative authority." 167

The Court of Appeal in Highpine held that Directive 056 was subordinate legislation and could not be interpreted as removing the discretion given to the Board. ${ }^{168}$ Further, the Court of Appeal has acknowledged that the regulator has been granted wide powers of discretion with respect to its interpretation of Directive 056. In Petro-Canada 2012, the Court held that directives were "'home rules' drafted, promulgated, revised, amended and repealed by the Board." ${ }^{169}$ Review of Board decisions will likely be subject to a high degree of deference and subject only to review on questions of law or jurisdiction.

Yet the Board's discretion with respect to Directive 056 is not limitless, as shown by the Petro-Canada 2012 and Kelly \#1 decisions. This caselaw suggests that the courts may be willing to direct matters back to the regulator for reconsideration on questions of to whom industry consultation and notification is required - that is, questions more closely aligned with standing. This is a natural conclusion since questions of standing involve specific rights to public participation granted under REDA (that is, with respect to regulatory hearings) rather than the mere "opportunities" for public participation - the focus of this article. And yet, since this article is concerned largely with the question of "what is," rather than "what

Alberta, Energy Resources Conservation Board, "Processing of Applications for Sour Oil and Gas Development in Light of the Court of Appeal Decision in the Matter of Kelly v. Alberta (Energy Resources Conservation Board) and Grizzly Resources Ltd.," Bulletin 2009-41 (Calgary: ERCB, 13 November 2011), online: <www.edmonton.ca/city_government/documents/PDF/bulletin-2009-41.pdf>. Shaun Fluker, "The Continuing Mystery of Standing at the Energy Resources Conservation Board" (14 February 2011), ABlawg (blog), online: <ablawg.ca/wp-content/uploads/2011/02/blog_sf_mcginn ercbfeb2011.pdf $>$.

Highpine, supra note 144 at para 9.

Petro-Canada 2012, supra note 154 at para 10. 
should be," perhaps the conclusion is beneficial after all. By recognizing that the Regulator has considerable discretion in matters of consultation and notification under Directive 056, and acting on the assumption that any practical and timely increases in opportunities for public participation will need to originate from the regulator, then such regulator-generated initiatives achieve greater significance.

However, before we turn to examine the AER's new regulatory initiatives (in Part V, below), it should be noted that while applications to the Court of Appeal appealing Board decisions on industry notification and consultation have been met with limited success, this has not forestalled the criticism of these participation limitations outside the court system. ${ }^{170}$ For example, concern has been expressed over "power imbalances" between public participants (specifically landowners) and industry applicants. It has been argued that landowners do not have the equivalent degree of knowledge or expertise necessary to challenge industry applicants. ${ }^{171}$ Conversely, it has also been argued that "the threat of a hearing on the part of a landowner is a powerful tool that gives companies a strong incentive to negotiate and compromise." ${ }^{\prime 12}$ Other issues include:

(i) how "public" is such consultation and how much does it involve Albertans as citizens rather than as immediately affected landowners?;

(ii) while good business practice for industry, does such consultation really amount to "public participation in energy and natural resources development in Alberta"?; and

(iii) how relevant are such consultations to the ultimate decisions made by the regulators "in the public interest"? ${ }^{173}$

See Fluker, "The Right to Public Participation," supra note 129: Chiasson, "What's Standing," supra note 135; Vlavianos, "Issues and Challenges," supra note 19. It is notable that much of this literature centres around the question of standing.

Vlavianos, "Issues and Challenges," ibid at 5.

Ibid.

Ibid. Landowners appear to be specifically provided for under the REDA Regime. REDA, supra note 10, s 15 provides: "Where the Regulator is to consider an application or to conduct a regulatory appeal, reconsideration or inquiry, it shall, in addition to any other factor ... consider any factor prescribed by the regulations, including the interests of landowners." Section 3 of the REDA General Regulation, supra note 93 discloses the additional factors which the Regulator must consider. These are:

(a) the social and economic effects of the energy resource activity,

(b) the effects of the energy resource activity on the environment, and

(c) the impacts on a landowner as a result of the use of the land on which the energy resource activity is or will be located. 


\section{Public Consultation - Proposed NeW REQUIREMENTS FOR HYDRAULIC FRACTURING OPERATIONS}

As we have seen, the broad notification and consultation requirements prescribed in Directive 056 continue to apply to hydraulic fracturing operations. Yet arguably they fall short of addressing all of the particular issues unique to hydraulic fracturing operations.

Public concerns over hydraulic fracturing in general also have begun to be noted and addressed in AER decisions. ${ }^{174}$ But to date this issue has not been directly considered by Alberta Courts. ${ }^{175}$

Alberta regulators have not overlooked these concerns or the changing oil and gas industry. On the contrary, the Alberta regulator has been commended for its ability to "lead and get out in front of its critics" $" 176$ with respect to the release of the Discussion Paper and the PBR Pilot Project. These two regulatory initiatives will now be explored in greater depth.

\section{A. The Discussion PAPER}

The Discussion Paper proposes a new regulatory framework for unconventional resources, including hydraulic fracturing operations. Release of the Discussion Paper has been heralded as a "welcome development because it provides a practical example of how a regulator can

See e.g. ConocoPhillips Canada Operations Ltd Application for Two Wells and a Multiwell Battery Willesden Green Field (11 February 2014), 2014 ABAER 001 at paras 1, 37, 42, online: AER <www. aer.ca/documents/decisions/2014/2014-ABAER-001.pdf> [ConocoPhillips]. In ConocoPhillips, the AER approved an application for a licence to drill two horizontal wells and a multiwell pad, and to construct and operate a multiwell battery. Two local residents filed statements of concern with the AER. During the consultation process, the residents noted that one of their concerns was "fracturing" (ibid at para 32). At the subsequent hearing, the panel of AER hearing commissioners concluded that ConocoPhillips, the industry applicant, made satisfactory efforts to consult with the residents and that it met Directive 056 notification and consultation requirements (ibid at para 42). Further, with respect to the residents' water well and groundwater protection concerns, the panel of the AER noted that ConocoPhillips had exceeded the requirements for shallow groundwater protection (ibid at para 62). The panel considered the possibility of surface water and groundwater being affected by, inter alia, the fracture propagation into the protected groundwater zone during hydraulic fracturing on the horizontal legs of the proposed wells and found the risk highly unlikely. As a consequence, after carefully considering "all of the evidence," the panel approved the applications (ibid at para 1).

175 But see Ernst v EnCana Corp, 2013 ABQB 537, 570 AR 317 [Ernst \#1]; Ernst v EnCana Corp, 2014 ABQB 672, 598 AR 331 [Ernst \#2]. Both cases involve a claim by a landowner against EnCana Corporation (EnCana), the ERCB, and what is now Alberta Environment. In Ernst \#1, the claims against EnCana were "for damaging the Ernst water well and the Rosebud aquifer... It is alleged that ... EnCana engaged in a program of shallow drilling to extract methane gas from coal beds" by hydraulic fracturing (ibid at para 1). In Ernst \#2, the claim against the ERCB, inter alia, was negligence in its administration of its statutory regulatory regime (ibid at para 3). The claim against Alberta Environment in Ernst \#2 alleges that Alberta Environment, inter alia, owed a duty to Ernst to protect her water well from foreseeable contamination caused by drilling for shallow methane gas, that it failed to conduct a reasonable investigation and to take remedial steps to correct damage, and that Alberta Environment breached its duty to Ernst (Ernst\#2, ibid (Statement of Claim, Plaintiff at paras 78-79)). It is noteworthy that Ernst \#1 and Ernst \#2 involve hydraulic fracturing to extract coalbed methane (CBM), which can be a very different process than when hydraulic fracturing is used in shale gas plays. For example, CBM may take place in close proximity to relatively shallow aquifers, while shale gas deposits tend to lie deeper. See Alberta Energy Regulator, Directive 035, “Baseline Water Well Testing Requirement for Coalbed Methane Wells Completed Above the Base of Groundwater Protection" (Calgary: AER, 2006), online: <www.aer.ca/documents/directives/Directive035.pdf $>$.

176 Nigel Bankes, “A New Approach to Regulating Unconventional Resource Plays in Alberta: The ERCB Takes a Bold Step Forward" (10 January 2013), ABlawg (blog), online: <ablawg.ca/wp-content/uploads/ 2013/01/Blog_NB_ERCB_Regulating_Unconventional_Oil_and_Gas_Jan2013\%E2\%80\%A6.pdf $>$ [Bankes, "Bold New Step"]. 
take the initiative in trying to manage cumulative impacts and the risks associated with the application of known technologies to new challenges."177

Commentators have also argued that the Discussion Paper represents an "expanded role for public involvement that affords an opportunity to shape the future patterns of resource development with a particular emphasis on regional planning and cumulative effects (i.e., play-based approach), risk management, performance reporting, and continual improvement processes." 178 Specifically, it has been argued that the new approach espoused in the Discussion Paper "emphasizes a collaborative approach to plan for and manage the unique risk characteristics of a particular unconventional resource play." 179

One of the key challenges listed in the Discussion Paper is stakeholder engagement. Accordingly, the Paper outlines broad goals for the regulation of unconventional resources which have the potential to expand public participation in a number of ways.

First, the proposed time frame for notification and consultation appears to be updated by the Discussion Paper. The Discussion Paper speaks to the early and meaningful engagement of stakeholders where play-focused regulation will enhance engagement by ensuring early disclosure of play development plans. ${ }^{180}$ These play development plans must provide enough detail to show how stakeholder engagement will be addressed. ${ }^{181}$

Second, at present, industry applicants must apply for every energy resource-related activity separately. This includes each well on a multiwell pad. The Discussion Paper specifically identifies this issue and provides that "consultation and notification distances for landowners or residents do not reflect concentrated pad activities or extended periods of activity on the pad site." 182 Further, the Discussion Paper provides that landowner and resident notification will be "expanded ... to ensure awareness of proposed activities, that concerns are heard, that pad sites are properly located, and that mitigative measures are applied." ${ }^{\prime 183}$ Finally, stakeholder engagement will not only be required with respect to sitespecific pad notification requirements, but will also be required to address consultation at the community level. ${ }^{184}$

It could be argued that the Discussion Paper represents the potential for a greater number of stakeholders to be engaged in meaningful consultation on hydraulic fracturing operations in Alberta. However, it does not deal with specific requirements or mechanisms to achieve its broad principles and goals. To a certain extent, the specifics have been left to the PBR Pilot Project, which is, in part, an ongoing exercise in testing proposed mechanisms designed to achieve the Discussion Paper's broader principles.

Ibid. Bankes also argues that the Discussion Paper is "fully consistent with the planning approach espoused by the Alberta Land Stewardship Act, SA 2009, c A-26.8 and the Land-use Framework."

Lucas, Watson \& Kimmel, supra note 4 at 145.

Ibid at $145-46$.

Discussion Paper, supra note 7 at 4.

Ibid at 3. Play-development plans must include "involving the local community and other stakeholders throughout the full life cycle of the project, from early in the play development through to abandonment, to determine which issues are of particular concern and how they might be addressed" (ibid at 3). Ibid at 16.

Ibid.

Ibid. 


\section{B. The Play-Based Regulation Project (PBR Pilot Project)}

The PBR Pilot Project builds on the principles established in the Discussion Paper and includes more specific regulatory requirements for public consultation and public participation. However, at this time, the requirements outlined in the PBR Pilot Project only apply to an area of the Duvernay shale play near Fox Creek, Alberta. ${ }^{185}$ While participation in the PBR Pilot Project remains voluntary, the AER has provided that the PBR Pilot Project represents the "start of a change in the way that the AER regulates the energy sector." 186

If implemented on a more widespread basis, the PBR Pilot Project has the potential to increase the public's opportunities for participation with respect to key areas of concern specific to the unique nature of hydraulic fracturing operations. First, the PBR Pilot Project includes more specific details with respect to the AER's "single application" plan. According to the AER, "[t]he single application is an integrated, risk-based, and play-focused submission to the AER requesting approval for an energy development project and its related activities." ${ }^{187}$ Consequently, stakeholder engagement under the PBR Pilot Project is to be conducted for the entire project instead of for each individual activity. With respect to stakeholder consultation, the intent of the single application or single approval process is to "provide stakeholders, including First Nations and Métis, with enough information to understand the effects of a proposed project and meaningfully engage in the REDA public participation process if they so choose."

A complete single application will include a stakeholder engagement plan in which the applicant must "describe its completed, current, and planned stakeholder engagement activities for the life cycle of the project.... The extent of these activities will depend on the nature, size, and scope of the project." ${ }^{\prime 189}$

Concerning the timing of stakeholder engagement, the PBR Pilot Project contemplates that industry applicants must engage meaningfully stakeholders in the project area throughout the project's life cycle. An industry applicant must begin its stakeholder engagement program

Hydraulic fracturing operations are generally required for the exploration and exploitation of shale resources such as the Duvernay shale play. See Alberta Energy Regulator, "Play-Based Regulation Pilot Project," online: <www.aer.ca/about-aer/spotlight-on/pbr-pilot-project>.

PBR Pilot Project, supra note 8 at 2. Already there is evidence that some industry applicants and segments of the public have adopted the principles of the Discussion Paper and voluntarily engaged in the PBR Pilot Project. For example, see Lochend Industry Producers Group (LIPG), online: $<$ www.lipg.ca $>$, a coalition of industry operators formed in 2011 who have voluntarily devised a cooperative strategy in line with the PBR Pilot Program for the Lochend area north of Cochrane. Part of this co-operative strategy involves preventing the proliferation of industrial facilities by collaborating on pipelines and access roads, controlling heavy equipment traffic, and setting standards for water and waste management. Further, LIPG asserts that it regularly communicates with the community in the area, providing information disclosure with open houses, newsletters, and an internet site.

PBR Pilot Project, ibid at 5 [footnotes omitted].

Ibid at 6.

Ibid at 8. The application must include project information, a stakeholder engagement plan, a risk management plan, and a reporting plan. The intent is to go beyond wells and directly related facilities to include, for example, proposed pipelines and roads, as well as existing development of all sectors (for example, energy, forestry, recreational, and municipal) in the local and regional area. 
before filing an application with the AER. It is intended that "as many concerns as possible are resolved before the application is submitted."190

Another benefit of this approach arises with respect to Public Lands Act approvals. Prior to the REDA Regime, some notice may have been provided for Crown lands dispositions for energy resource related activities. However, there were no real opportunities for public participation. By bringing these applications within the "single approval" process, there may be more opportunities for public participation in these matters.

The play-based single application approach also has the potential to address a major concern of stakeholders in the past. That is, the perceived inability of the regulatory regime to evaluate cumulative impacts on the environment. Stakeholders have argued that they have been denied the opportunity to discuss the effects of cumulative impacts in regulatory reviews. ${ }^{191}$ One of the "key challenges" of unconventional oil and gas development listed in the Discussion Paper is the "regional effects of activities on the landscape." 192 The AER has maintained that the new proposed approach will "result in better opportunities to understand and mitigate cumulative impacts." ${ }^{193}$ Consequently, this may lead to increased opportunities for public participation in the review of these cumulative impacts.

The PBR Pilot Project provides that collaboration with stakeholders is fundamental to the play-based regulation approach. Play-based regulation (one of the foundations of the PBR Pilot Project) has been accorded cautious approval. The Environmental Law Centre (ELC) summarized:

\begin{abstract}
Play-based regulation can help regulatory decision making keep pace with the complexity of modern environmental issues, particularly with unconventional resource development. The public engagement component takes good steps towards providing participation that fits the regulators' mandate. Efficiency should enhanced by earlier public engagement. This approach can produce overall reductions in costs and delay and uncertainty — a business case sometimes called the "exchange of efficiency.","194
\end{abstract}

Further, play-based regulation was commended as an "excellent approach," focusing on "solutions, relationships and a non adversarial process." ${ }^{195}$ However, the ELC's comments on the proposed regulation of unconventional resources were not without reservation. The ELC cautioned:

Ibid at 9. Emerging concerns post-approval must also be "identified, assessed, and resolved by the approval holder" (ibid).

See e.g. Steve Kennett \& Dan Woynillowicz, A Review of Alberta Environment's Proposed Regulatory Framework for Managing Environmental Cumulative Effects (The Pembina Institute, December 2007), online: $<$ www.pembina.org/reports/Pembina-review-AB-Env-ce.pdf $>$; Vlavianos, "Single Regulator," supra note 59; Nigel Bankes, "Constitutional Questions and the Alberta Energy Regulator" (24 October 2013), ABlawg (blog), online: <ablawg.ca/wp-content/uploads/2013/10/Blog NB Fort McKay_First Nation v Alberta Energy Regulator October 2013.pdf>.

Discussion Paper, supra note 7 at 8.

PBR Pilot Project, supra note 8 at 2 .

Cindy Chiasson \& Adam Driedzic, "Comments to Alberta Energy Regulator on Play-Based Regulation Pilot and Stakeholder Engagement" (Edmonton: Environmental Law Centre, 25 July 2014) at 1 [ELC Commentary].

Ibid at 3 . 
The challenge is in stakeholder identification and role assignment. Participation must fit the mandate of the new agency. Efficiency concerns are increasing and there are conflicting views on the impact of environmental representation. The "public interest" mandate attached to regulatory agencies remains illdefined and is hard to avoid despite the shift in language from the Energy Resources Conservation Act (ERCA) to the Responsible Energy Development Act (REDA). ${ }^{196}$

The PBR Pilot Project also appears to reference the possibility of a new enforcement mechanism:

The GoA [Government of Alberta] also has numerous parallel initiatives that align with the AER's move towards PBR. For example, the GoA is investigating the role of mineral tenure in increasing responsible development and planning. Alberta Energy may use this pilot as an opportunity to test extending petroleum and natural gas agreements based on a requirement for industry to produce plans that ensure collaboration with other stakeholders and responsible resource development. ${ }^{197}$

If Alberta Energy chooses to proceed with a decision to link mineral tenure decisions to proof of adequate stakeholder engagement, this could be a significant new motivator for industry. ${ }^{198}$

Despite these potential increased opportunities for public participation, it also must be recognized that even "play-based" regulatory reviews may not encompass all of the unique elements which arise in hydraulic fracturing operations. For example, the first "key challenge" identified in the Discussion Paper was the management and protection of water. ${ }^{199}$ As recognized in the Discussion Paper, hydraulic fracturing operations used in shale gas development require the use of large volumes of water. This generates issues surrounding the regulation of water sourcing, transportation, recycling, storage, and disposal. ${ }^{200}$ These issues would more likely be addressed at the policy-making stage than in play-based regulatory reviews. As recognized in the ELC Commentary, "[e]fforts to maintain a policy-regulatory divide will be challenged where play-based regulation mandates the regulator to decide broader issues."201

Before concluding, it must be recalled that this section has focused predominantly on the "preliminary application stage" of a potential hydraulic fracturing operation. This is only one stage in the broader regulatory regime. Not insignificantly, section 5.1 of the PBR Pilot Project confirms that the requirements in REDA and the REDA Rules "regarding public notice of application, opportunity to file statements of concern, alternative dispute resolution, hearing on an application (if held), and regulatory appeal apply to a single application and single approval."202

\section{$196 \quad$ Ibid at 1.}

197 PBR Pilot Project, supra note 8 at 4-5.

198 See Bankes, "Bold New Step," supra note 176 and Professor Bankes' reflections on whether additional "big sticks" will be available to the AER to assist in implementing and enforcing the new performancebased regulation.

$199 \quad$ Discussion Paper, supra note 7 at 8.

200 Ibid.

201 ELC Commentary, supra note 194 at 1.

The environmental impact assessment provisions of the EPEA and its regulations, which govern when an environmental impact assessment would be required, also continue to apply to all projects, including those in the PBR Pilot Project area, see AER, "Frequently Asked Questions," supra note 83. 
Once a complete application is received, public notice of the application will be provided in accordance with the REDA Regime. Any person who believes that they may be directly and adversely affected by the application has 30 days to file a statement of concern with the AER. Therefore questions of "directly affected" and "directly and adversely affected" continue to play a predominant role in whether a person will have the opportunity to participate in a hearing before the regulator. ${ }^{203}$

\section{CONCLUSION}

The exploration and development of unconventional resources such as shale gas by hydraulic fracturing techniques has the potential to be a "game changer" with significant economic benefits to Albertans. Yet with any intensive, widespread industrial activity, the potential for significant risk to the environmental and human health exists. Critics of the use of hydraulic fracturing technology have claimed that hydraulic fracturing is almost unregulated in Canada and Albertans are in danger of being shut out of discussions on the development of Alberta's natural resources. As we have shown, the importance of public engagement in the development of such economically beneficial and potentially risky resources has been highlighted both in general and specifically with respect to hydraulic fracturing operations.

In Alberta, alongside the increased exploration and development of unconventional resources and the increased use of hydraulic fracturing, we have seen corresponding regulatory changes, including the creation of a new regulator, the implementation of the new $R E D A$ regulatory regime, and many regulatory changes and initiatives focused directly on unconventional resources in general and hydraulic fracturing in particular.

As we have seen, the AER actively solicited feedback and input in the development of not only Directive 083 (the hydraulic fracturing directive), but also the Alberta government's Regulatory Enhancement Project, the REDA Regime, and the new regulatory initiatives introduced in the Discussion Paper. The exploratory or 'trial' nature of the PBR Pilot Project also appears to be premised on the basis that public and industry input is not only allowed but necessary to the proper evolution of the project.

However, such opportunities do not represent an open public review system designed to provide a forum for public interest participants (and citizens) beyond the narrower range of stakeholders contemplated. Further, the voluntary nature of these rule-making exercises must be underlined. There is no legal right to public participation in rule-making of this kind.

When faced with the question of whether, as a result of all of these changes, we have seen an increase in the opportunities for public participation in the regulation of hydraulic

A discussion of public participation opportunities at this next stage of the regulatory process is beyond the scope of this article; however, it is recognized that this stage involves a number of complex issues, including: public and private interest standing; the AER's discretion with respect to "statements of concern"; a comparison of the public's "entitlement" to a hearing before the AER, the ERCB, and the ESRD; a review of how the "directly affected" or "directly and adversely affected" tests can permit or restrict public opportunities to participate; the effect of the elimination of the Environmental Appeal Board jurisdiction on public opportunities to participate in energy resource applications; and opportunities to "intervene" in an energy resource-related hearing. 
fracturing at an operational level, we come to a disappointing conclusion. Currently, with the exception of the compulsory requirements on fracturing fluid disclosure, there are no mandatory public notification or public consultation requirements that specifically apply to hydraulic fracturing. There has not been an increase in public participation opportunities in Alberta with respect to hydraulic fracturing operations.

But perhaps, as this article has shown, this conclusion is premature. The Alberta Court of Appeal has consistently held that the regulator of oil and gas activities in Alberta has been granted wide powers under statute and has considerable discretion in creating the rules around which oil and gas resource development will occur. The sufficiency of public notification and consultation is a question of fact for the regulator to determine.

The regulator has used its powers in the past in the drafting and interpretation of public notification and consultation guidelines such as those found in Directive 056. However, more recently, through its two regulatory initiatives, the Discussion Paper and the PBR Pilot Project, the AER appears to be moving towards increasing the opportunities for public participation, both through a wider definition of "stakeholder" and a more inclusive, projectorientated approach. These regulatory initiatives speak to expanded consultation requirements at the individual and community levels. The timing of stakeholder consultation is expected to occur earlier and extend further than previous consultation requirements. The single application approach, which encompasses Public Lands Act approvals and the need to consider regional effects of activities on the environment, suggests that the regulator, in its discretion, may also be trending towards more comprehensive consultation.

Whether these ideals will transmit into increased practical opportunities for public participation, and how these new regulatory initiatives will be incorporated into the REDA Regime and the AER hearing process, remains to be seen. 